\title{
A prioritised inventory of crop wild relatives and wild harvested plants of Tunisia
}

\author{
Ridha El Mokni (D) - Giulio Barone (D) - Nigel Maxted (D) - Shelagh Kell (D) • \\ Gianniantonio Domina $(\mathbb{D}$
}

Received: 3 November 2021 / Accepted: 29 December 2021 / Published online: 19 January 2022

(C) The Author(s) 2022, corrected publication 2022

\begin{abstract}
An inventory of crop wild relatives (CWR) and wild harvested plants (WHP) occurring in Tunisia, based on the integration of the last available floristic checklists, is presented. The taxa were prioritised according to economic value of the related crop, potential for crop improvement, threat status, endemism, inclusion in the ITPGRFA (Annex I) and average annual contributions to dietary energy (kilocalories) per capita per day by applying a scoring system based on 4 priority levels. Of a total of 2912 taxa belonging to the Tunisian Flora, 2504 CWR and/
\end{abstract}

Supplementary Information The online version contains supplementary material available at https://doi. org/10.1007/s10722-021-01340-z.

R. El Mokni

Laboratory of Botany and Plant Ecology (SNA-214), Department of Life Sciences, Faculty of Sciences of Bizerte, University of Carthage, 7021 Jarzouna, Bizerte, Tunisia

R. El Mokni

Laboratory of Silvo-Pastoral Resources, Silvo-Pastoral Institute of Tabarka, University of Jendouba, BP. 345, 8110 Tabarka, Tunisia

R. El Mokni

Laboratory of Botany, Cryptogamy and Plant Biology, Faculty of Pharmacy of Monastir, University of Monastir, Avenue Avicenna, 5000 Monastir, Tunisia or WHP (86\% of the total), from 143 families and 686 genera, were identified, 2445 of which are CWR and 847 are WHP. In detail, 1654 are solely CWR and 59 are WHP only, whereas 788 are both CWR and WHP. The final priority list for active conservation includes 1036 CWR (43\% of the total CWR taxa), with 139 taxa rated as high priority, 660 medium priority and 237 low priority. The final priority list for WHP is composed of 344 taxa and includes eight high priority, 254 medium priority and 82 low priority taxa. Our results confirm Tunisia as a hotspot of CWR and WHP diversity in the Mediterranean area. The inventory here proposed provides the basis for the development and implementation of a more targeted national CWR/ WHP conservation strategy for Tunisia.

G. Barone $(\bowtie) \cdot$ G. Domina

Department of Agricultural, Food and Forest Sciences

(SAAF), University of Palermo, Viale delle Scienze,

90128 Palermo, Italy

e-mail: giulio.barone01@unipa.it

N. Maxted · S. Kell

School of Biosciences, University of Birmingham, Edgbaston, Birmingham B15 2TT, UK 
Keywords Crop wild relative $\cdot$ Wild harvested plants · Plant genetic resources · Food security · Conservation $\cdot$ Ethnobotanical use

\section{Introduction}

Crop wild relatives (CWR) are wild plant species closely related to cultivated species of socio-economic value, such as those providing food, fodder, industrial materials, ornamentals, and biofuels (Maxted et al. 2006). CWR play a central role for breeding purposes due to their potential or actual ability to supply beneficial genetic traits for crop improvement (Harlan and de Wet 1971; Maxted et al. 2006, 2010). The Mediterranean region is a centre of diversity for wheat (Triticum aestivum L.), barley (Hordeum vulgare L.), olive (Olea europaea L.), carrot (Daucus carota L.), cabbages (Brassicaceae) and other major food crops. In this area, some native plants host useful traits that can improve the cultivation of their related crops, such as Brassica insularis Moris, a SW Mediterranean endemic that occurs in coastal habitats, which confers resistance to the fungal pathogen Leptosphaeria maculans (Sowerby) P.Karst. in hybrids with $B$. oleracea (Mithen and Lewis 1988), or Aegilops ventricosa Tausch, which is used in providing resistance to numerous pests and diseases in common wheat (e.g., cyst nematode, leaf rust, stem rust) (Vincent et al. 2013). Additionally, CWR, as components of natural and semi-natural ecosystems, together with other wild species play a role in ecosystem functioning and in broader environmental sustainability and the maintenance of ecosystem services (FAO 2019a). In the frame of a more sustainable, low-input agriculture (Crespo-Herrera and Ortiz 2015; Duru et al. 2015), CWR often represent an under-exploited source of genes for ensuring food security (FAO 2006, 2009a). Furthermore, global challenges, such as climate change and a continuous rise in the human population, are posing a huge threat to biodiversity, affecting both CWR and wild harvested plants (WHP) - undomesticated species typically harvested from the wild by local people. Consequently, potential loss in beneficial and useful traits (Hajjar and Hodgkin 2007; Castañeda-Álvarez et al. 2016; Dempewolf et al. 2017) suitable for granting everyone access to nutritious and safe food, is emerging as a major concern, together with the awareness that protecting biodiversity and ensuring food security are part of a single agenda (Godfray 2011). Food security is pursued by several means and, among them, by the development of new varieties resistant to diseases, pests, or environmental stresses, such as extreme temperatures, drought, and flooding, that require less inputs for their cultivation. Many crop varieties are being replaced with stress tolerant varieties to ensure yield stabilization and continuity of cultivation in altered environments due to climate change, soil degradation or pollution (Mammadov et al. 2018). Crop improvement can be obtained by using existing crop agrobiodiversity (Jacobsen et al. 2015) but also broader-based diversity can be introgressed through the introduction of traits from their wild relatives, which are adapted to diverse habitats and have not passed through the genetic bottleneck of domestication (Vollbrecht and Sigmon 2005; Hajjar and Hodgkin 2007). The conservation of these plant genetic resources (PGR) is therefore a priority for agriculture and environmental sustainability because it can help to increase sustainable crop production (Reeves et al. 2016) and reduce negative impacts on future food security.

WHP have for millennia provided the primary source of fuel, construction material and food, and even today they are a valid supplement to the diet and medicine for peoples of the Mediterranean Basin (Vavilov 1926; Harlan and de Wet 1971; Morales et al. 2013; Landucci et al. 2014; Maxted and Vincent 2021). According to the World Health Organization, $65 \%$ of the world population rely on plant derived products as sources of therapeutic agents for their health care (Fabricant and Farnsworth 2001). Lavania (2005) estimated that nearly 6000 species of plants are exploited for their traditional, herbal, or medicinal characteristics. There is also a clear link between medicinal plants and food as demonstrated by the Mediterranean diet (Willett 2006; Sofi et al. 2010) where leafy vegetables are collected to add variety and nutrition to the diet (Heywood 1999). These plants, used as a food source locally, also have the potential to increase food security and nutrition of people living in harsh environments (Ulian et al. 2020). After a surge in their use at the turn of the two World Wars or during famine and food scarcity periods (Petropoulos et al. 2018), and a slight decline at the end of the twentieth century, today the interest in these plants as additional 
sources of healthy functional food, non-nutrient bioactive compounds and medicine has been rekindled, not only in developing countries (Keller et al. 2005; Termote et al. 2011), but also in the wealthy ones (Padulosi et al. 2011; Menendez-Baceta et al. 2012; Sánchez-Mata et al. 2012; Geraci et al. 2018; Ulian et al. 2020). Nowadays, much of the research on these plant species is focused on their nutritional, toxicological, and medicinal aspects (Soumaya et al. 2013; Zouari et al. 2013; Pinela et al. 2017), but there are still other features to be investigated, such as agronomic aspects for their potential domestication and cultivation (Molina et al. 2016). An example is Argania spinosa (L.) Skeels, whose oil is exported all over the world and represents a real economic resource for Morocco (Lybbert et al. 2011). Conserving WHP is therefore of paramount importance not only from a biodiversity point of view but also because they represent a substantial part of that ethnobotanical knowledge which is today at risk (Schultes 1991; Menendez-Baceta et al. 2012). They contribute either directly or indirectly to the balance of ecosystems, providing several services, such as landscape diversity, bee-activity and pollination, and pest control (Cardinale et al. 2012; Bretagnolle and Gaba 2015).

Like all the other wild plants, both CWR and WHP are subject to threats of genetic erosion due to excessive exploitation, habitat modification and population reduction (Brummitt and Bachman 2010; Bilz et al. 2011; Kell et al. 2012). The importance of these PGR and the need to conserve them are recognized through international commitments made by governments such as the Second Global Plan of Action for the Conservation and Sustainable Utilization of Plant Genetic Resources for Food and Agriculture (Second GPA), a strategic framework for global conservation and sustainable use of PGR (FAO 2011), and the International Treaty on Plant Genetic Resources for Food and Agriculture (ITPGRFA) (FAO 2009b). The issue of PGR conservation has also been stressed by the Strategic Plan for Biodiversity 2011-2020, its Aichi Targets (https://www.cbd.int/sp/targets/), and the Global Strategy for Plant Conservation 2011-2020 (GSPC) (CBD 2012), which are now under an update process for the preparation of the post-2020 Global Biodiversity Framework (CBD 2018). It plans to implement broad-based action to bring about a transformation in society's relationship with biodiversity. Therefore, the need of national CWR and WHP inventories as a basis for planning sound conservation strategies is well recognized (Maxted et al. 1997; Kell et al. 2008; CBD 2015; FAO 2017). The Mediterranean Basin is the third world hotspot of CWR diversity in terms of the number of global priority CWR after Western Asia and China (Vincent et al. 2013). In theory, all CWR/WHP should be preserved, but using the broad concept of CWR (Maxted et al. 2006) can ultimately result in the inclusion of an extremely large number of taxa. For example, in Europe, where $83 \%$ of the entire flora can be classified as CWR in a broad sense (Kell et al. 2008), active conservation of all taxa would obviously exceed the available resources. Hence, the need for prioritisation of taxa emerges when effective conservation strategies must be planned and conducted (Ford-Lloyd et al. 2008; Maxted and Kell 2009; Kell et al. 2017). Maxted et al. (2013) distinguish between checklists, annotated checklists, and inventories. In summary, checklists report only the names and some basic data; annotated checklists add more data about the related crops; inventories add to the checklists important data that characterize the considered taxa (related crop, degree of relatedness, Red List status, etc.).

A global CWR inventory containing 1667 priority taxa, 195 of which are from North Africa (Algeria and Morocco), was developed by Vincent et al. (2013). At the same time the importance of local, national, and regional inventories has been recalled several times (Maxted et al. 2007; Maxted and Kell 2009). In Europe, all countries already have national CWR checklists generated by the PGR Forum project (Kell et al. 2005, 2008) and some have prioritised inventories of CWR (e.g., Magos Brehm et al. 2008; Fielder et al. 2015; Labokas et al. 2018; Ciancaleoni et al. 2021). For Africa, there is a regional inventory of CWR of the Southern African Development Community (SADC) region (Allen et al. 2018) and one of the North African region (Lala et al. 2018). However, even if there are several SADC countries with CWR checklists and inventories (e.g., Allen et al. 2019; Mponya et al. 2020), this information is lacking for the North African countries. A checklist of 5780 CWR taxa from North Africa, representing $76 \%$ of its flora, was recently presented (Lala et al. 2018). The inventory reported 502 taxa identified as a priority for conservation.

With the aim of extending and deepening the information available about the conservation and 
threat status of CWR and WHP in North African countries, in this paper we present a prioritised inventory of crop wild relatives and wild harvested plants of Tunisia based on the latest available checklist of the Tunisian flora (Le Floch et al. 2010).

\section{Materials and methods}

\section{CWR and WHP checklist}

The checklist of the flora of Tunisia (Le Floch et al. 2010) was integrated with the data available in the African Plant Database (version 3.4.0) (http://www. ville-ge.ch/musinfo/bd/cjb/africa; Dobignard and Chatelain 2010-2013) and Euro + Med Plantbase (http://ww2.bgbm.org/EuroPlusMed).

Based on this integrated checklist, CWR taxa, all taxa within the same genus as a crop, were identified, after checking for synonyms, using the crop genus list of Kell et al. (unpublished data), similarly to other authors' approaches (e.g., Kell et al. 2015; Contreras-Toledo et al. 2018; Rahman et al. 2019). The taxonomic nomenclature was harmonized by referring to International Plant Name Index (IPNI 2020), The Plant List (2021) and Plants of the World online (POWO 2019). The level of crop relatedness of each taxon, according to the Gene Pool (Harlan and de Wet 1971) and Taxon Group concepts (Maxted et al. 2006), was determined by using the resources available at Germplasm Resources Information Network (USDA 2021) and at The Harlan and de Wet CWR inventory (Vincent et al. 2013). Ancillary information in the database were compiled according to Thormann et al. (2017): family; genus; species; taxonomic rank; native, introduction or invasive status; endemicity; Red List status; common and scientific name of the related crop; type and level of relatedness; local cultivation status (i.e., whether under cultivation or not); gross production value of the related crop; synonyms and use category.

The WHP taxa identification was based on their known uses in Tunisia and derived from direct knowledge and interviews conducted during the last two decades across the country by the first author. Ethnobotanical surveys were carried out in the villages of 19 out of the 24 Governorates of Tunisia in the period from September 2001 to May 2021, as shown in Table 1. Folk uses of plants were investigated through interviews and discussions with the knowledgeable persons of the visited villages or/and communities (AFG: Aged Forest Guards, EF: Elderly Farmers, S: Shepherds, THS: Traditional Herb Sellers). The specimens mentioned by the informants were identified on site or collected together in the field to confirm the identity of the discussed ethnospecies. The gathered data were filled in a database reporting the diverse known uses/remedies of different used parts of each ethnospecies. The identified taxa were then sorted and matched with their related scientific names. In order to verify and confirm our findings, the results of these surveys were then compared and integrated with relevant previous ethnobotanical studies within various Tunisian regions/localities (e.g., Le Floc'h 1983; Boukef et al. 1982; El Mokni 2004; Ben Haj Jilani et al. 2011; Ben Ismail 2013; Ben salah et al. 2019; Dop et al. 2020; Karous et al. 2021). This ethnobotanical database was finally combined in the abovementioned checklist of the flora of Tunisia to select the taxa definable as WHP. The use categories chosen were: drink, environmental, ethnobotanical, fodder, food, food addition, fuel, material, medicinal, ornamental, and social. In addition, it is indicated if the taxa investigated are poisonous or if they are of interest for honey production.

\section{Prioritisation}

The prioritisation process used the following criteria (derived and adapted from Maxted and Kell 2009; Magos Brehm et al. 2010, 2017; Kell et al. 2015, 2017; Lala et al 2018): (a) the economic value of the related crop, derived from FAOSTAT (2012-2016) for Tunisian agricultural gross production (FAO 2019b), and organized according to the classifications of products used for the statistical purposes in FAOSTAT Commodity List; (b) the degree of relatedness following the Gene Pool (GP) concept (Harlan and de Wet 1971): GP1B (for wild or weedy forms of the crop, i.e. crossing is easy and hybrids are generally fertile), GP2 (secondary wild relatives, i.e. less closely related species from which crossing is still possible but more difficult), GP3 (tertiary wild relatives, i.e. species from which gene transfer to the crop is impossible, or requires sophisticated techniques). When information on crossability between CWR and crop species was unavailable, the Taxon Group (TG) concept (Maxted et al. 2006): TG1b (same species as the crop), TG2 (same series or section as the crop), TG3 (same 
Table 1 Ethnobotanical surveys conducted in Tunisia from 2001 to 2021 with the different types of informants

\begin{tabular}{|c|c|c|c|c|}
\hline Tunisian biogeographical entity & Governorate & Village/Community & Period & Informants \\
\hline \multirow[t]{4}{*}{ Kroumirie } & \multirow[t]{4}{*}{ Jendouba } & Aîn Draham & \multirow[t]{4}{*}{ 2001-2021 } & AFG \\
\hline & & Fernana & & AFG \\
\hline & & Ghar Dimaou & & AFG-EF \\
\hline & & Tabarka & & $\mathrm{S}$ \\
\hline \multirow[t]{7}{*}{ Mogods } & \multirow[t]{5}{*}{ Bizerta } & Ghar El Melh & \multirow[t]{5}{*}{ 2001-2021 } & $\mathrm{S}$ \\
\hline & & Mateur/Bazina & & AFG-EF \\
\hline & & Mateur/Sidi Nsir & & AFG \\
\hline & & Ras Jebel & & $\mathrm{AFG}$ \\
\hline & & Utique & & EF-THS \\
\hline & \multirow[t]{2}{*}{ Beja } & Beja South/M'farig & 2014-2015 & $\mathrm{EF}-\mathrm{S}$ \\
\hline & & Nefza & 2012-2021 & AFG \\
\hline \multirow[t]{3}{*}{ Valley of Medjerda } & \multirow[t]{3}{*}{ Beja } & Beja North/El Manchar & \multirow[t]{3}{*}{ 2014-2018 } & $\mathrm{EF}-\mathrm{S}$ \\
\hline & & Beja North/Ksar Mezouar & & $\mathrm{EF}-\mathrm{S}$ \\
\hline & & Testour & & $\mathrm{S}$ \\
\hline \multirow[t]{3}{*}{ Northeastern part } & \multirow[t]{2}{*}{ Bizerta } & Bizerta North/Nadhour & \multirow[t]{2}{*}{ 2001-2021 } & AFG \\
\hline & & Bizerta South/Rimel & & AFG \\
\hline & Tunis & Ariana/Sidi Amor & 2012-2014 & AFG-S \\
\hline \multirow[t]{3}{*}{ Cap Bon } & \multirow[t]{3}{*}{ Nabeul } & Beni Khiar/Ghardaïa & \multirow[t]{3}{*}{ 2018-2020 } & $\mathrm{EF}$ \\
\hline & & Beni Khiar/Soumâa & & $\mathrm{EF}$ \\
\hline & & Haouaria & & AFG \\
\hline \multirow[t]{11}{*}{ Central Tunisia } & Monastir & Moknine/Amira & 2015-2021 & $\mathrm{S}$ \\
\hline & Mahdia & Kerker & & $\mathrm{S}$ \\
\hline & Sousse & Enfidha/Takrouna & & $\mathrm{S}$ \\
\hline & \multirow[t]{3}{*}{ Siliana } & Kesra & \multirow[t]{3}{*}{ 2017-2018 } & AFG \\
\hline & & Makthar & & AFG \\
\hline & & Siliana South/Sidi Hmada & & AFG \\
\hline & \multirow[t]{3}{*}{ Kasserine } & Thelpete & \multirow[t]{3}{*}{ 2004-2011 } & $\mathrm{EF}$ \\
\hline & & Rouhia & & $\mathrm{S}$ \\
\hline & & Sbeitla & & $\mathrm{S}$ \\
\hline & Kairouan & Oueslatia & 2015-2016 & $\mathrm{S}$ \\
\hline & Sidi Bouzid & Sidi Bouzid North/Mghila & 2014-2015 & $\mathrm{EF}-\mathrm{S}$ \\
\hline \multirow[t]{6}{*}{ Tunisian Dorsal } & Beja & Teboursouk & 2018-2019 & $\mathrm{S}$ \\
\hline & \multirow[t]{3}{*}{ Le Kef } & Dahmani & \multirow[t]{3}{*}{ 2019-2020 } & $\mathrm{S}$ \\
\hline & & Nebeur & & $\mathrm{S}$ \\
\hline & & Sers & & $\mathrm{S}$ \\
\hline & Zaghouan & El Fahs & 2004-2011 & $\mathrm{EF}$ \\
\hline & & Zaghouan & & AFG \\
\hline Southern Tunisia & Medenine & Medenine North/Tajera & 2001-2004 & AFG-S \\
\hline & & Medenine South/Béni Ghzaeil & & $\mathrm{S}$ \\
\hline & & Medenine South/Naffeteya & & $\mathrm{S}$ \\
\hline & & Béni Khdèch/Ain Tanout & & $\mathrm{S}$ \\
\hline & Sidi Bouzid & Sidi Bouzid South/Bouhedma & 2012-2018 & AFG \\
\hline & Tataouine & Bir Lahmer & 2001-2004 & $\mathrm{S}$ \\
\hline & & Douiret & & $\mathrm{S}$ \\
\hline & & Remada & May 2021 & THS \\
\hline
\end{tabular}


Table 1 continued

\begin{tabular}{|c|c|c|c|c|}
\hline Tunisian biogeographical entity & Governorate & Village/Community & Period & Informants \\
\hline & \multirow[t]{2}{*}{ Tozeur } & Tozeur East/Dghoumes & 2014-2015 & AFG \\
\hline & & Tozeur North & 2001-2011 & S \\
\hline & \multirow[t]{2}{*}{ Gabes } & Chenini & 2011-2015 & S \\
\hline & & Matmatas & & AFG-S \\
\hline & \multirow[t]{2}{*}{ Gafsa } & El Ksar/Lalla & 2017-2019 & AFG-THS \\
\hline & & Metlaoui/Selja & 2017-2018 & THS \\
\hline
\end{tabular}

$A F G$ : Aged Forest Guards, EF: Elderly Farmers, $S$ : Shepherds, THS: Traditional Herb Sellers

subgenus as the crop) and TG4 (same genus as the crop). When CWR were related to multiple crop taxa, the most closely related species was used to define the GP or TG (Jarvis et al. 2015), and in case of GP/TG parity, the most economically important related crop cultivated in the country was given priority; (c) threat status based on the IUCN Red List of Threatened Species (IUCN 2021) and other threat assessments (CoE 1979; Garzuglia 2006; MEDD 2009); (d) endemicity to Tunisia or North Africa (African Plant Database; MEDD 2009; Dobignard and Chatelain 2010-2013; Domina and El Mokni 2019); and, (e) the related crop importance estimated by the combined use of inclusion in Annex I of the ITPGRFA (FAO 2009b) and, only for CWR, the inclusion on ITPGRFA Annex I or the Food supply contribution calculated as the average annual (2014-2018) contributions to dietary energy (Kcal/capita/day) for the Northern African region (FAO 2021). (Table 2).

The CWR were identified as all taxa within the same genus as a crop with some exceptions due to nomenclatural updates or to genera universally recognized as ancestors of other cultivated genera (e.g., Aegylops ancestor of Triticum). The taxa were scored, on a scale of 0 to 10 , against each of the 5 above-mentioned criteria, and a final score (FS) was calculated as the average of the scores for all criteria. Four priority levels were then established: High $-5 \leq \mathrm{FS} \leq 10$, Medium-2 $\leq \mathrm{FS}<5$; Low- $0<\mathrm{FS}<2$ and No-Priority if $\mathrm{FS}=0$. Criteria (a), (b), and (e) were not applied for WHP taxa. Opuntia stricta (Haw.) Haw., a known alien invasive species (Le Houérou 2002; GRIIS 2018) was excluded from the prioritisation process. Furthermore, taxa known only to occur in cultivation (i.e., those in GP1a and TG1a that have no wild distributional range), were excluded from the analysis.

\section{Results and discussion}

\section{Checklist description}

The obtained integrated checklist of the Tunisian flora accounted for 2912 taxa, including subspecies, varieties, and botanical hybrids. Among them, 2504 CWR and/or WHP taxa ( $86 \%$ of the total), belonging to 143 families, 686 genera and 2301 species, were identified. This high percentage is expected, and similar results have been found for other countries and regions since, at this stage, CWR are considered in a broad sense (i.e., any taxon within the same genus as a crop) and without the exclusion of introduced, invasive and cultivated taxa (Kell et. al. 2008, 2015). Approximately $94 \%$ of the CWR and/or WHP taxa (2343 taxa and 2147 species) are native to Tunisia, 6.4\% (160 taxa) are introduced, and only Opuntia stricta is invasive (Le Houérou 2002; GRIIS 2018).

The checklist contains of 2445 CWR taxa in 2243 species, 643 genera, and 137 families, whereas 847 taxa are WHP distributed in 365 genera and 113 families. Seven hundred and eighty-eight taxa are both CWR and WHP, whereas 1654 are solely CWR and 59 only WHP. Among these taxa, which form the basis for the CWR inventory, there are 644 CWR taxa related to 167 socio-economically important crops according to criteria $a$ and $e$. The ten richest families of CWR in the integrated checklist are Fabaceae, Poaceae, Amaranthaceae, Brassicaceae, Asteraceae, Rosaceae, Apiaceae, Alliaceae, Polygonaceae, Solanaceae (in order of importance), which include 551 taxa-22.5\% of the total CWR (Fig. 1). The most represented CWR genera are: Trifolium L. (32 taxa related to clovers), Astragalus L. (31 taxa related to milkvetch), Allium L. (27 taxa related to onion, leek and garlic), Vicia L. (25 taxa related to broad bean and 


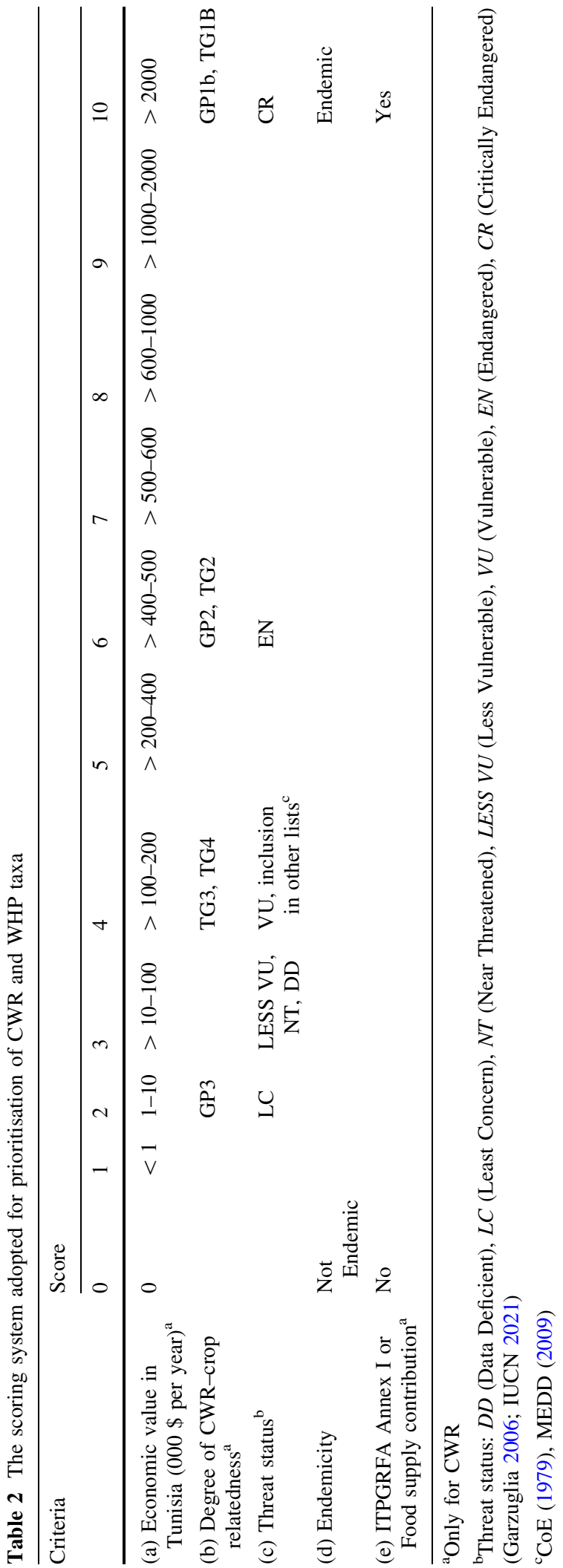

vetch), Medicago L. (23 taxa related to medick and alfalfa), Rumex L. (19 taxa related to sorrel), Daucus L. (17 taxa related to carrot), Lathyrus L. (17 related to pea vine), Atriplex L. (16 related to orach), Lotus L. (16 taxa related to bird's-foot trefoil), Amaranthus L. (15 taxa related to amaranth), Carthamus L. (12 taxa related to safflower), Linum L. (11 taxa related to flax), Prunus L. (11 taxa related to almond, apricot etc.), Solanum L. (11 taxa related to potato, tomato and eggplant), Avena L. (10 taxa related to oat), Rosa L. (10 taxa related to rose) (Fig. 2).

The identified CWR species for Tunisia account for about $10 \%$ of the crops and CWR of Europe and the Mediterranean area according to Kell et al. $(2005,2008)$ and for $6 \%$ of the total Euro-Mediterranean flora (40,783 taxa according to Raab-Straube et al. 2016). These data noticeably differ from those reported for Tunisia by Lala et al. (2018), (2445 vs. 1792 CWR taxa, respectively). This discrepancy might be due mainly to a different comprehensiveness of the database used for the flora of Tunisia, along with differences resulting from the new genus list used to define CWR taxa (Kell et al. unpublished), and taxonomic and distributive updates. Compared with other national CWR checklists, Tunisia, in its 163,610 $\mathrm{km}^{2}$, has a similar number of CWR taxa as Germany (2874 taxa, 357,386 km²; PGRDEU 2021; Labokas et al. 2018), Norway (2538 taxa $385,207 \mathrm{~km}^{2}$; Phillips et al. 2016), Armenia (2518 taxa 29,743 km²; Avagyan 2008; Heywood 2011), Portugal (2262 taxa; 92,212 $\mathrm{km}^{2}$ Magos Brehm et al. 2008, 2010) and United Kingdom (2109; 242,495 km²; Fielder et al. 2012), but much less than other Mediterranean countries such as Italy and Greece (Kell et al. 2005, 2008; Ciancaleoni et al. 2021). These similarities/dissimilarities are probably due, among other factors, to its north-south extent corresponding to a great local environmental diversity. On the other hand, this considerable amount of CWR confirms Tunisia as a valuable part of the North African hotspot of CWR diversity in the Mediterranean area (Vincent et al. 2013; Maxted and Vincent 2021).

The ten most numerous WHP families, corresponding to $56 \%$ of the total WHP taxa, are Fabaceae, Asteraceae, Lamiaceae, Poaceae, Euphorbiaceae, Apiaceae, Orchidaceae, Rosaceae, Brassicaceae, Cistaceae (in order of importance) (Fig. 3). This list of the most numerous families is comparable to those of other authors regarding different Mediterranean areas 


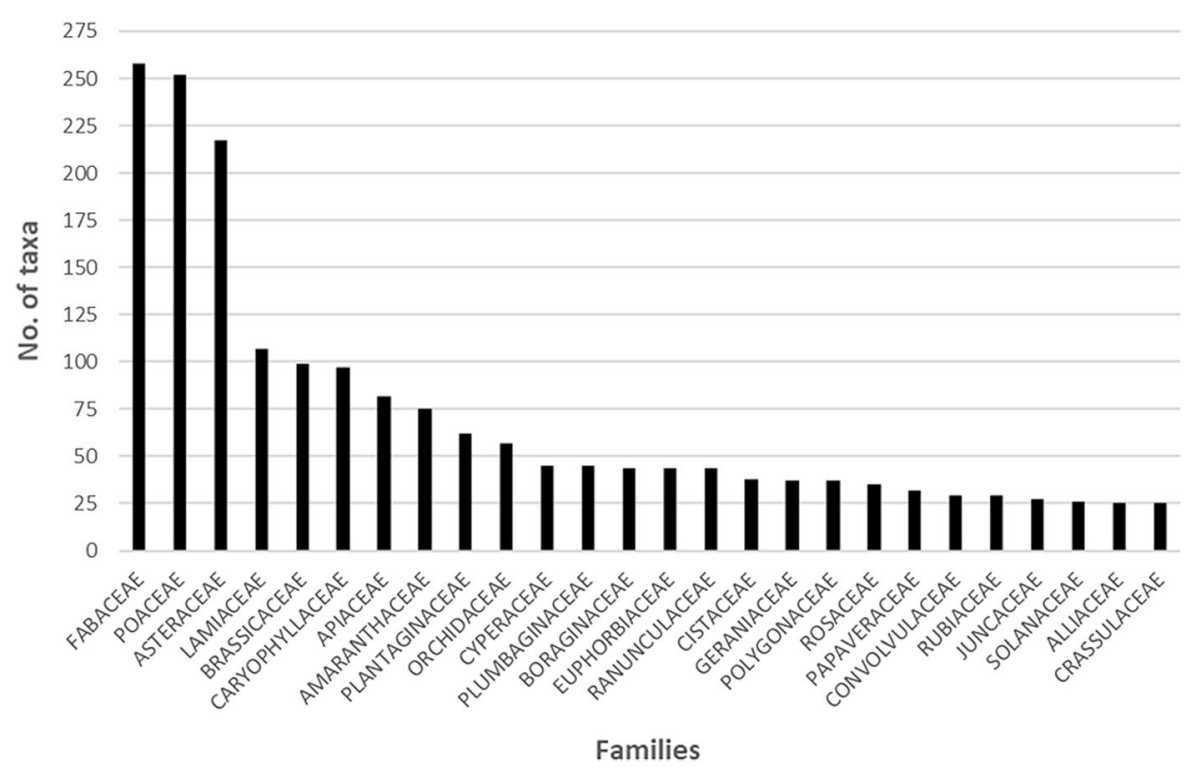

Fig. 1 Number of taxa belonging to the most represented CWR families in Tunisia

with similar environmental conditions such as Cyprus, Crete, Andalusia, Albania, Sicily, Egypt, and Morocco (Lentini and Venza 2007; Hadjichambis et al. 2008; Nassif and Tanji 2013), suggesting not only flora similarities but also intriguing, even if inextricable, connections between agrobiodiversity and cultural heritage. The ten most numerous genera are Euphorbia (39 taxa), Helianthemum (25), Ophrys (24), Allium (13), Dianthus, Hypericum and Medicago (9 each), Launaea, Lolium, Lotus (8 each) (Fig. 4). Altogether they represent $18 \%$ of the total WHP taxa.

As detailed before, the large majority (93\%) of WHP are also CWR. The total number of WHP taxa (847) accounted for $34 \%$ of the integrated checklist and about $2 \%$ of the total Euro-Mediterranean flora (Raab-Straube et al. 2016). In Tunisia, the numerical consistency of WHP with respect to the integrated checklist (34\%) is higher compared to that of Portugal ( $\approx 17 \%$; Magos Brehm et al. 2008) and Italy ( $\approx 22 \%$; Ciancaleoni et al. 2021). This could be due to several factors, such as the high diversity of medicinal and aromatic plants in the African continent (Sofowora 1993), a still higher usage of wild gathered food plants in the diet, especially in rural areas (Hadjichambis et al. 2008), and the relevance of WHP as additional income for the rural people (Borelli et al. 2020). Additionally, it should be noted that the total number of Tunisian WHP taxa can also be considered high when compared to Hadjichambis et al. (2008), who recorded 406 wild edible plants (WEP) in the circumMediterranean area, or to Nassif and Tanji (2013), who recorded 246 WEP species for Morocco, or to Zrira et al. (2013), who listed more than 200 species of aromatic and/or medicinal plants (PAM) for Maghreb. We found that 208 taxa (24\%) have some generic ethnobotanical use, $181(21 \%)$ are ornamentals, 129 $(15 \%)$ fodders, $117(14 \%)$ are used as human food, 94 $(11 \%)$ are medicinal, $82(9.5 \%)$ have a social use, 57 (7\%) have environmental uses, 57 (7\%) are used for beverages, $53(6 \%)$ as food additives. The 'Material' category was the least represented one with 17 taxa (Fig. 5). In addition, 108 (13\%) of them are poisonous and $88(10 \%)$ are used for honey production.

This distribution in use categories is comparable to that reported for Portugal, a Mediterranean country with a similar number of taxa (2262) in the national checklist (Magos Brehm et al. 2008), although with a different number of WHP taxa (497) but a similar ranking of the "top families" with the highest number of taxa (Asteraceae, Lamiaceae, Fabaceae). Interestingly, the percentage of WHP taxa that are used also for honey production resulted significantly higher in Tunisia (10\%) when compared to Italy $(1.8 \%$, Ciancaleoni et al. 2021) and Portugal (4.8\%, Magos Brehm et al. 2008). This is to be related to the high representativeness of these taxa among the top three 


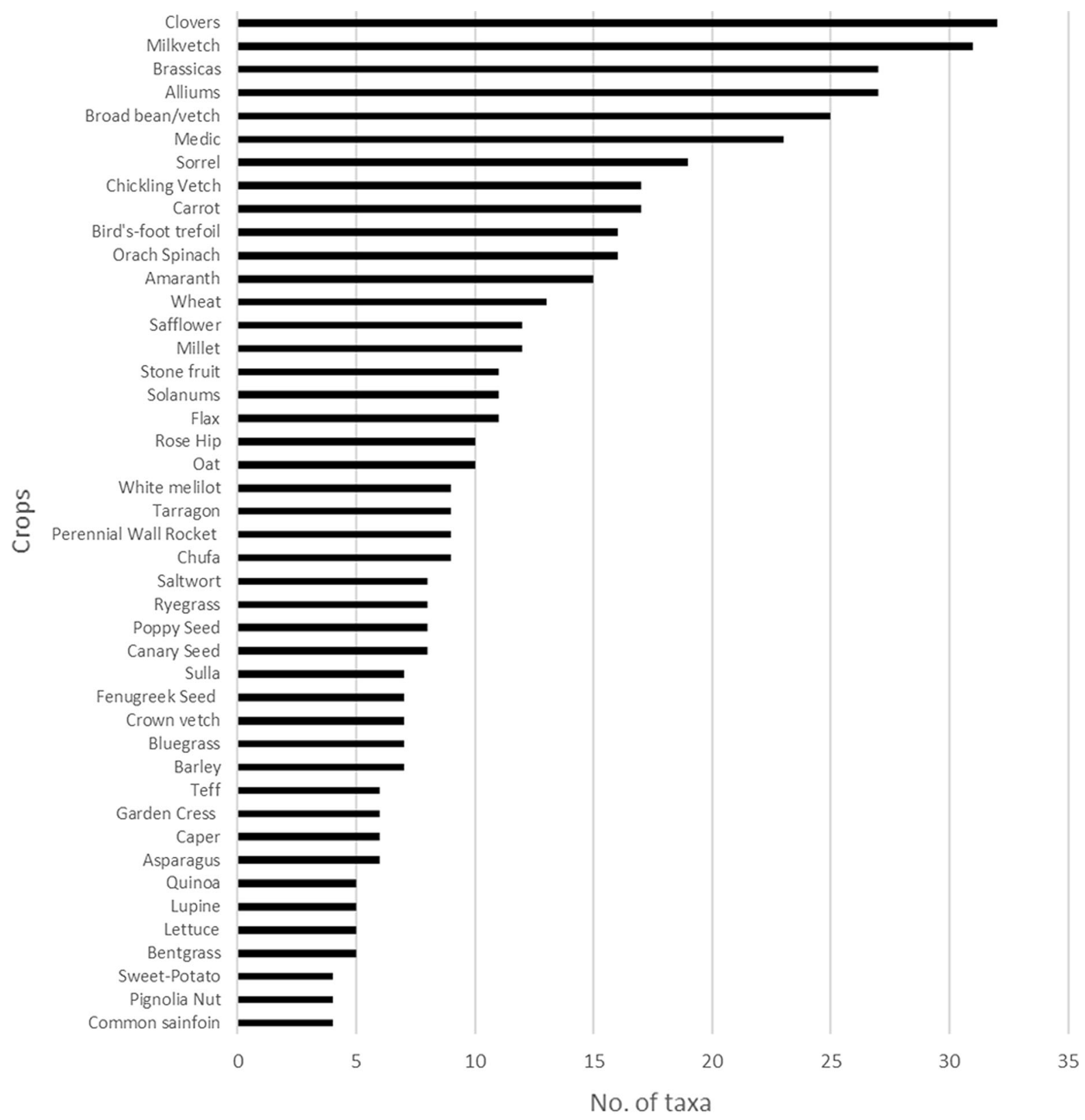

Fig. 2 Number of taxa belonging to the most socio-economically important crops cultivated in Tunisia

families composing the WHP list. Furthermore, it is noteworthy that almost one third of Tunisian WHP taxa have multiple uses. In fact, among the 847 WHP taxa, 205 fall in more than one use category, 77 in more than two, 21 in more than 3, 16 in more than 4 , while a maximum of 6 use categories is reported for 6 taxa. In three out of these last six cases, all belonging to Calamintha sp. pl. (Lamiaceae), an aromatic herbaceous genus rich in essential oils that is widely distributed in the Mediterranean area (Debbabi et al. 2020), the most frequent use category combination included medicinal, ornamental, food, food additives, beverages, and honey production. 


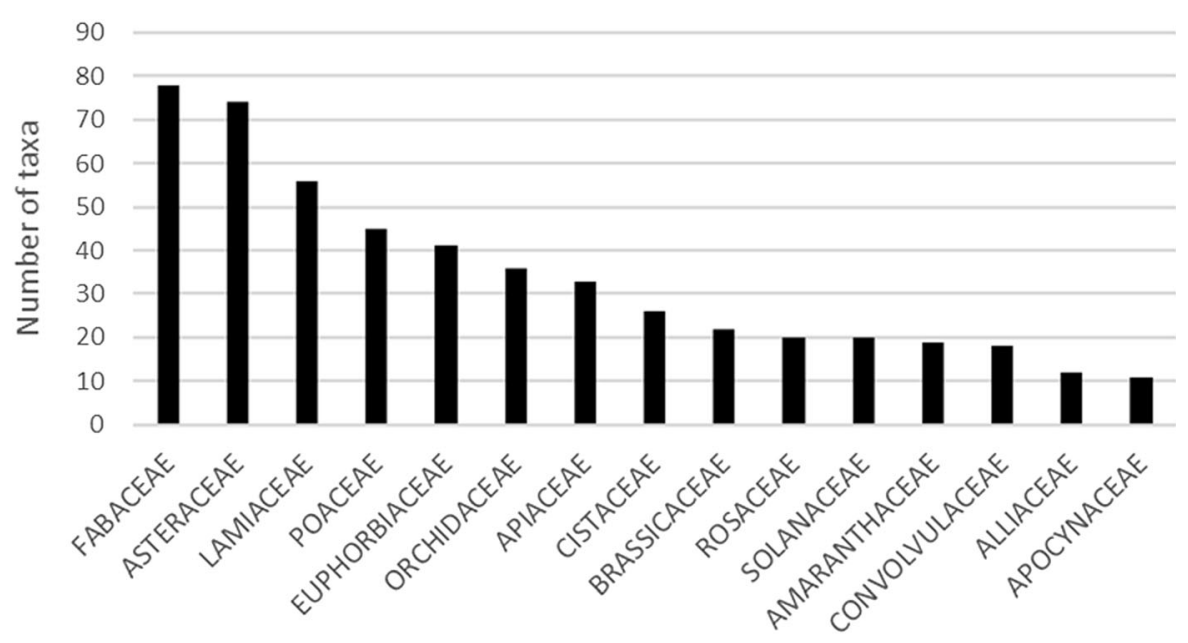

Families

Fig. 3 Number of taxa belonging to the most represented families of WHP in Tunisia

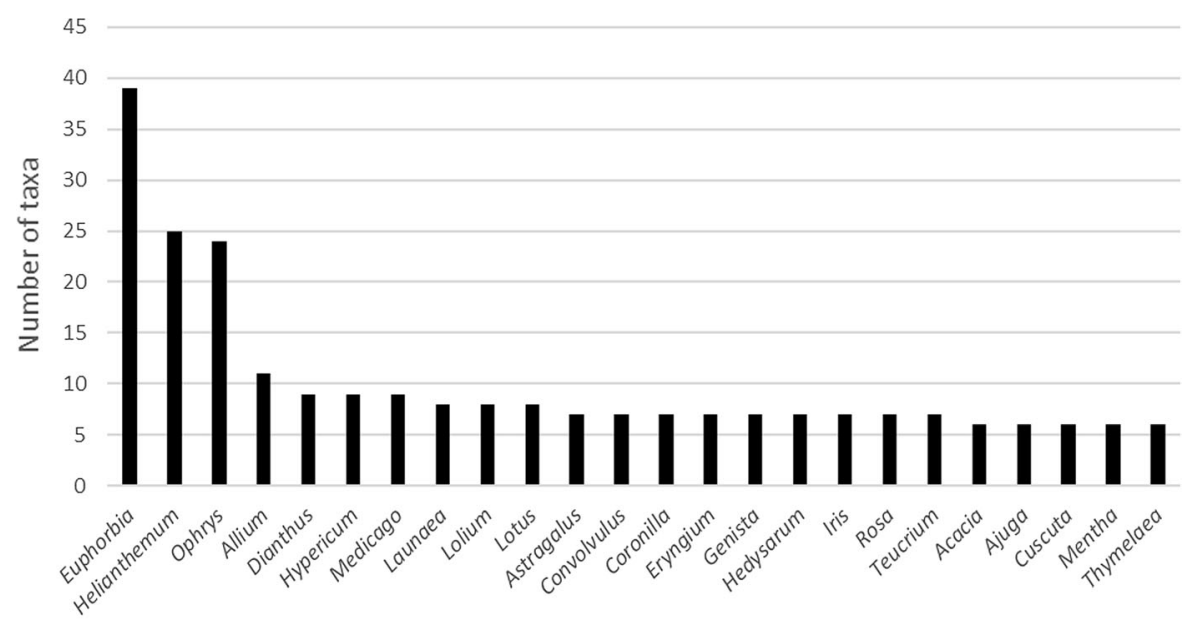

Genera

Fig. 4 Number of taxa belonging to the most represented genera of WHP in Tunisia

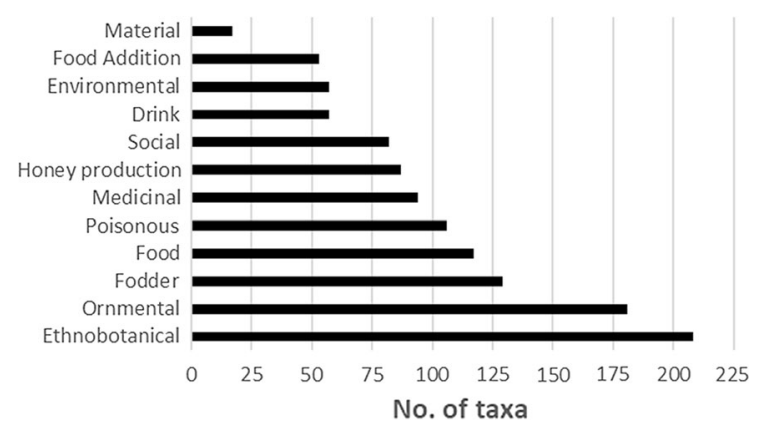

Fig. 5 Number of taxa according to WHP use categories
The most abundant use category (ethnobotanical) included several major taxa of aromatic interest that are also CWR. Concerning these aspects, it is interesting to note that there is a growing economic interest for aromatic and medicinal plants in most of the northern African countries. The area devoted to these plants in Tunisia is reported to pass from 1396 hectares to 2700 hectares between 2011 and 2016 (Neffati 2016), thus increasing the economic contribution of these species to the national income (Ministère des Affaires Locales et de l'Environnement 2019). On the 
other hand, this scenario highlights the need for a conservation strategy focusing on preserving WHP and CWR from being overexploited. This could be especially true for species needing urgent active conservation due to overharvesting, such as Lavandula L. sp. pl., Origanum L. sp. pl., Salvia L. sp. pl., and Thymus L. sp. pl., as evidenced for Morocco by Lamrani-Alaoui and Hassikou (2018). Among the WHP taxa included in the food use category, the most represented genera are Capparis L., Portulaca L., Diplotaxis DC., Rosa L., Calamintha Mill., Centaurea L., and Pinus L.
Prioritisation criteria application

The application of the above-mentioned methodology to the integrated checklist led to the selection of 2468 CWR and/or WHP (2409 CWR and 813 WHP taxa) native and introduced taxa suitable for prioritisation by the application of the five criteria:

\section{Economic value of the related crop}

A total of 329 CWR taxa (14\% of the total CWR) are related to a crop of economic importance (gross production value $>10,000 \$$ per year in Tunisia), according to FAOSTAT (FAO 2019b) and were therefore scored accordingly (Fig. 6). More than half

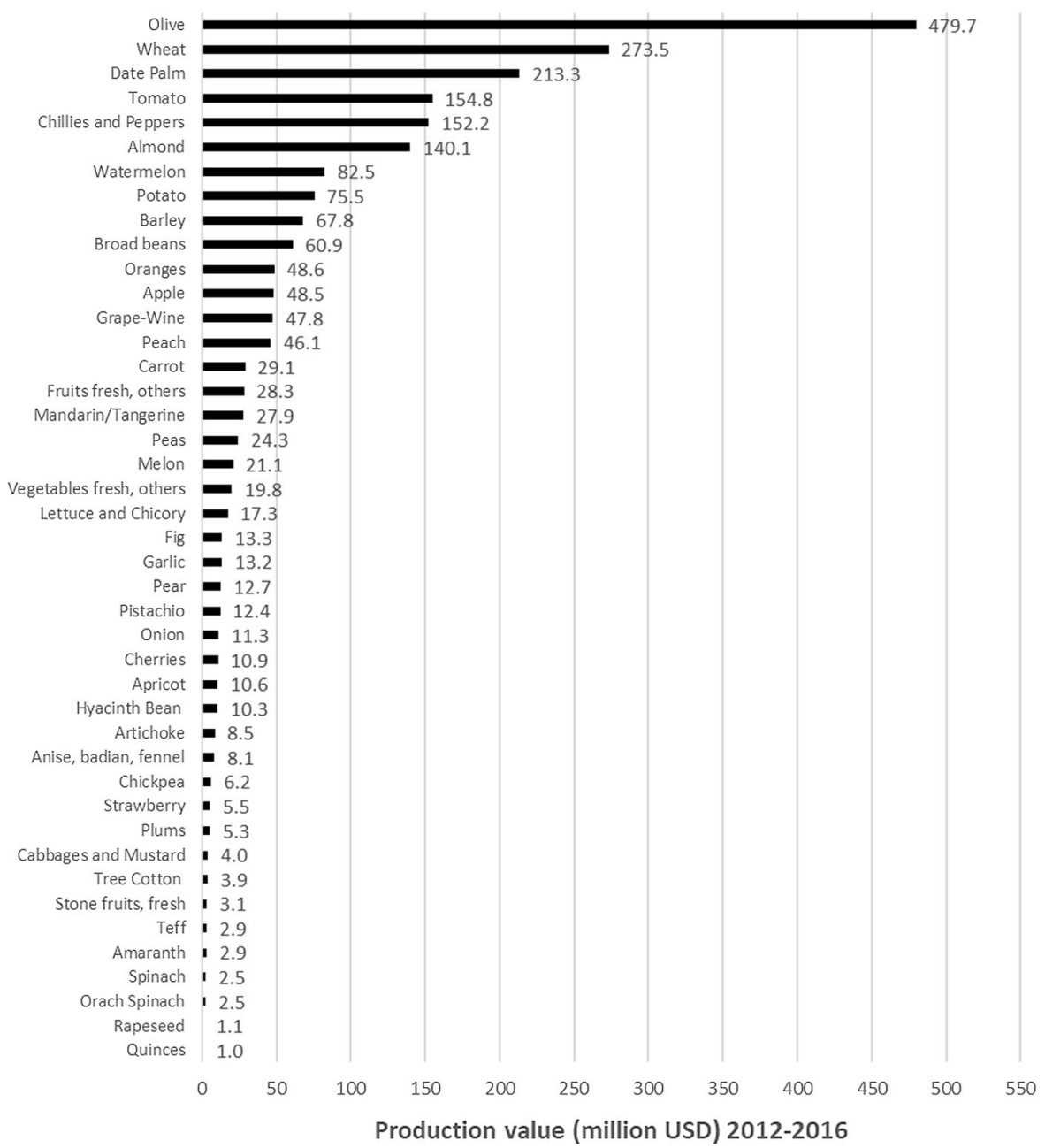

Fig. 6 Crops/crop groups of economic importance in Tunisia, showing their average gross production values (2012-2016) in Tunisia 


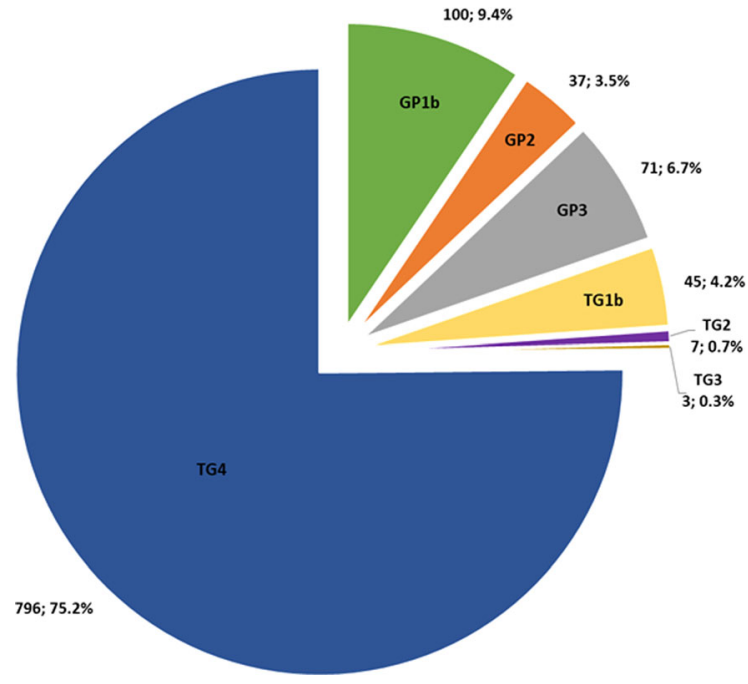

Fig. 7 Percentage distribution of prioritised taxa in the Gene Pool and Taxon Group categories

of these 329 taxa are included in seven FAOSTAT commodity groups, where "Vegetables, fresh not elsewhere specified (nes)", with 56 taxa, is the most represented one. The other commodity groups "Garlic", "Carrots and turnips", "Cereals nes", "Fruit, fresh nes", "Spinach" and "Cabbages and other brassicas", are represented by 23, 22, 21, 21, 18 and 16 taxa, respectively. The remaining 152 taxa belong to 44 other commodity groups. The 10 most represented families are Brassicaceae (43 taxa), Fabaceae (37), Amaranthaceae and Poaceae (35), Apiaceae (29),
Rosaceae (25), Alliaceae (24), Asteraceae (22), Polygonaceae (19), and Linaceae (11).

\section{Degree of relatedness}

Forty-four percent of the CWR in the checklist (1059 taxa) were scored according to criterion $b$. More precisely, 207 taxa were identified by their GP and 852 by their TG, with 144 taxa in GP1b and TG1b, 44 in GP2 or TG2, 71 in GP3, and 799 in TG3 or TG4 (Fig. 7).

\section{Threat status}

Four hundred and nine CWR/WHP taxa (16.3\% of the CWR/WHP) are considered threatened-314 of them (78\%) are listed in the IUCN Red List (2021), 108 (27\%) are included in the national report of the Ministère de l'Environnement (MEDD 2009) as threatened or vulnerable, $22(<1 \%)$ according to Garzuglia (2006), and three are listed in the Bern Convention. Figure 8 shows the number of prioritised taxa assigned to each category.

\section{Endemicity}

A total of 218 CWR and/or WHP taxa (9\% of the CWR/WHP) are endemic to Tunisia and North Africa (116 and 102, respectively). Among them, 18 taxa (e.g., Brassica insularis Moris, Daucus syrticus Murb., D. virgatus (Poir.) Maire, D. reboudii Coss.

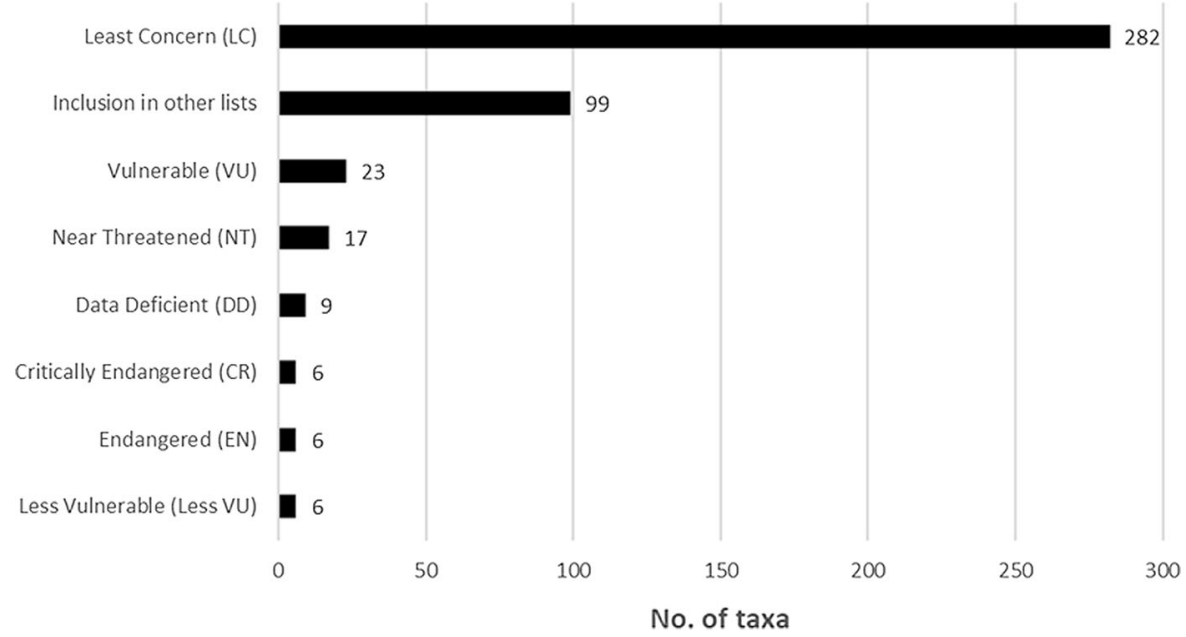

Fig. 8 The threat status of prioritised taxa in Tunisia (CoE 1979; Garzuglia 2006; MEDD 2009; IUCN 2012) 


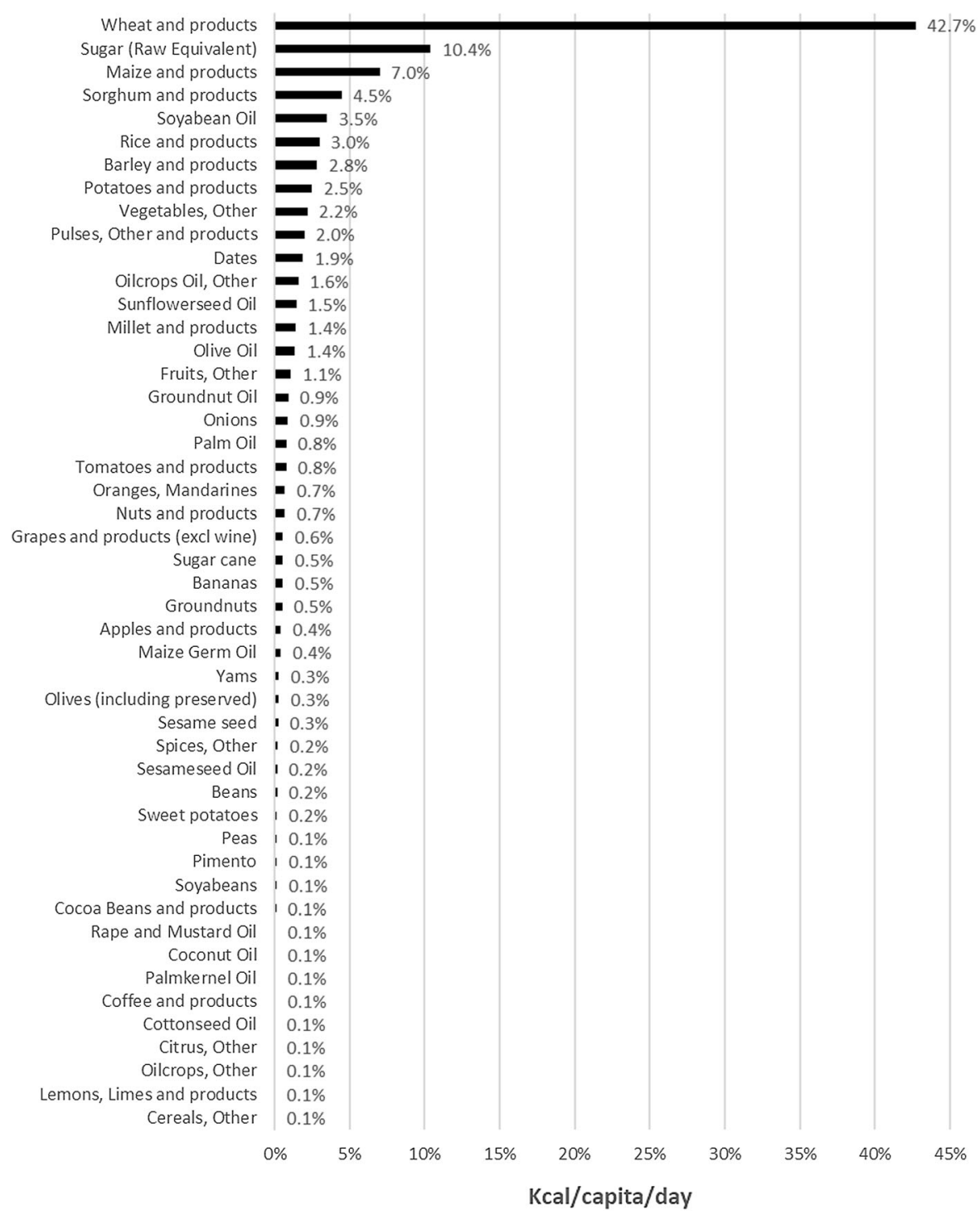

Fig. 9 Average annual contributions of crops/crop groups for North Africa to dietary energy (kilocalories) per capita per day of $0.1 \%$ or more over the period 2014-2018

ex Batt., Linum corymbiferum Desf. and Vicia fulgens Batt.) are related to crops of economic importance cultivated in Tunisia and in some cases to crops (cabbage, kale, carrot, and vetch) of worldwide interest according to ITPGRFA. The number of endemic taxa can be considered high in comparison to that reported for Tunisia by Libiad et al. (2020), probably due to discrepancies in the adopted database and/or nomenclatural attribution issues.

\section{Relevance for food security and nutrition}

Six hundred and eight CWR taxa (25\%) are related to crops included in Annex I of the ITPGRFA and/or contributing to annual dietary energy per capita per day (Kcal/capita/day) (Fig. 9). Among them, about one third are related to crops cultivated in Tunisia of significant economic importance, such as Brassica rapa L., Daucus carota, Hordeum vulgare, Malus domestica Borkh., Vicia faba L., and V. pannonica Crantz. The crops of high regional importance for food 
security in North Africa (i.e., those providing more than $3 \%$ of dietary energy supply) that also have wild relatives in Tunisia are Sorghum bicolor (L.) Moench, Triticum aestivum, T. dicoccum Schübl., T. durum Desf., T. polonicum L. and Vicia faba -wheat being the crop that provides the highest daily energy supply $(42.7 \%)$ among those with wild relatives in the country.

\section{Priority taxa}

The prioritisation process led to the selection of 1053 CWR/WHP taxa belonging to 101 families and 330 genera, accounting for $43 \%$ of the total CWR/WHP taxa listed in the integrated checklist. A comprehensive list of the priority taxa is given in the supplemental material (Appendix 1).

Regarding the WHP, there are 344 priority taxa (327 of which are both CWR and WHP, whereas 17 are WHP only), including 8 high priority taxa (Table 3), 254 medium priority and 82 low priority. The ten most represented families among the prioritised WHP taxa are Fabaceae (65 taxa), Poaceae (29), Asteraceae (21), Rosaceae (18), Brassicaceae (17), Lamiaceae (16), Apiaceae (15), Amaranthaceae (14), Alliaceae (10), and Orchidaceae (9). The most abundant genera are: Allium (10 taxa), Medicago (9), Lolium, Lotus, and Ophrys (8), Astragalus, Coronilla, Hedysarum and Rosa (7), Capparis and Euphorbia (6), and Artemisia, Centaurium, Diplotaxis, Genista, Mentha and Vicia (5). Among the 17 taxa which are only WHP, medium and low priority taxa were found (9 and 8, respectively). Preserving these genetic resources might result beneficial, as seen above, for various aspects. These plants harvested in the wild could represent, in fact, an additional nutritive intake and economic income for rural populations. At the same time, they can be a potential source of new marketable foods, active compounds or other secondary products that can stimulate the local economy. This is the case, for example, of two endemic high priority aromatic plants Artemisia saharae Pomel and Thymus algeriensis Boiss. \& Reut, sources of essential oils, with actual and potential medicinal uses (Zouari et al. 2012, 2014; Sobeh et al. 2020). Furthermore, preserving the WHP means, all together, protecting that ethnobotanical knowledge which is nowadays at risk of disappearing. Finally, it must be reminded that, as stressed by FAO (2019a), there is now the need to act in order to obtain a sustainable harvest from the wild, especially in the case of taxa identified as priorities for conservation.

The list of priority CWR includes 1036 taxa, with 139 taxa $(5.8 \%$ of the total CWR listed in the integrated checklist) classified as of highest priority for conservation (Tables 4 and 5), 660 taxa (27.4\%) of medium priority, and 237 (9.8\%) of low priority. One hundred and forty-four taxa $(13.8 \%$ of the priority CWR) belong to GP1b or TG1b and can therefore be used more easily in breeding programs, while 44 $(4.2 \%)$ are in GP2 or TG2. The great majority (80\%) are in GP3, TG3 and TG4, with 71, 3 and 756 taxa, respectively. The top ten CWR priority families are Fabaceae (233 taxa), Poaceae (116), Asteraceae (59), Brassicaceae (54), Amaranthaceae (50), Apiaceae (37), Lamiaceae and Rosaceae (29), Cyperaceae and Plumbaginaceae (27). The most abundant priority genera are: Trifolium (32 taxa), Astragalus (31), Ononis L. (29), Limonium Mill. (27), Vicia L. (25), Allium (24), Medicago (23), Rumex (19), Daucus, Juncus L. and Lathyrus L. (17). The top priority taxa related to the most socio-economic important crops, including some staple food, vegetables, and fodder, are in the genera Daucus (13 taxa), Aegilops L. (8), Brassica L., Prunus L. and Vicia (7), Allium (6), Avena L. (5), Linum L. and Sinapis L. (4). Many of these high priority taxa are documented or potential sources of beneficial traits. For example, Brassica insularis Moris (high priority GP2, relative of Brassica olerace $\mathrm{L}$ L.) is a regional endemic with a confirmed use for blackleg resistance (Mithen and Lewis 1988). Vicia sativa L. subsp. amphicarpa (L.) Batt. (GP1b relative of Vicia sativa L.), threatened by heavy grazing, seasonal drought, and erosion (Abd El Moneim and Elias 2003; Rowe and Maxted 2019), and classified as Near Threatened (NT), can be potentially used to confer resistance to broomrape (Sillero et al. 2005), as well as rust and Ascochyta blight (Rubiales et al. 2015).

Tunisia lies in the centre of origin of carrot (Daucus carota) and hosts a rich diversity of wild and rare related taxa (Mezghani et al. 2019; Simon et al. 2020). D. syrticus Murb. (high priority in our inventory and GP1b), one of the few 18-chromosome carrot wild relatives, 6 wild subspecies (GP1b) of D. carota L., and 10 other native species of the same genus are examples of such richness. Consistently to Mezghani et al. (2019), D. reboudii Batt. and D. virgatus (Poir.) 


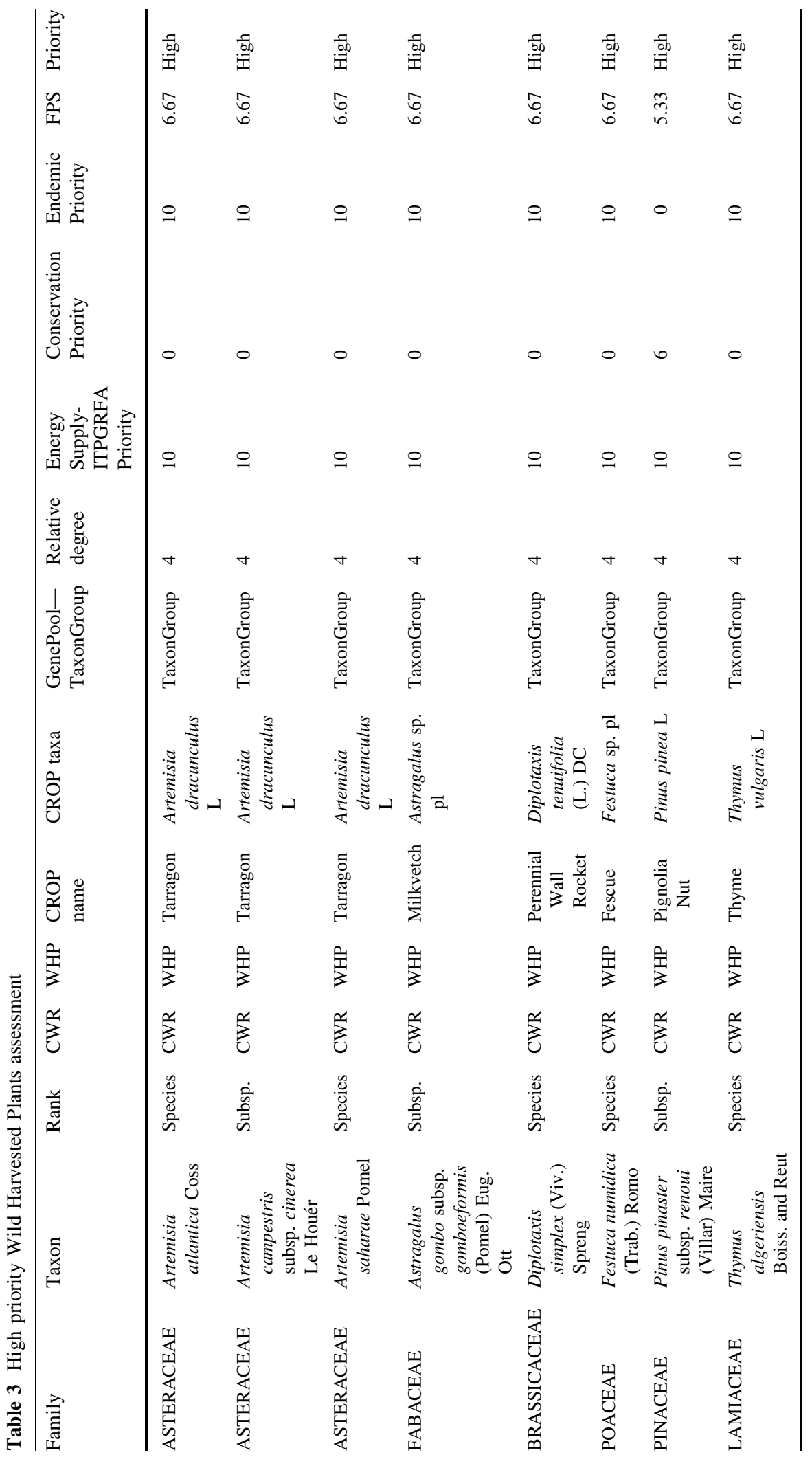


Table 4 High priority Crop Wild Relatives assessment

\begin{tabular}{|c|c|c|c|c|c|c|c|c|c|c|c|c|c|c|c|}
\hline 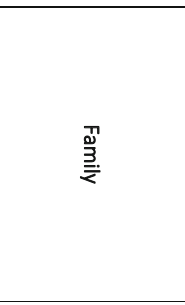 & $\begin{array}{l}\vec{y} \\
\stackrel{x}{0}\end{array}$ & $\begin{array}{l}\text { 껌 } \\
\text { 궂 }\end{array}$ & $\sum_{D}^{n}$ & 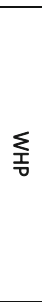 & 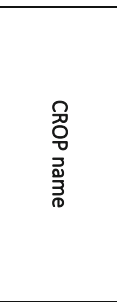 & 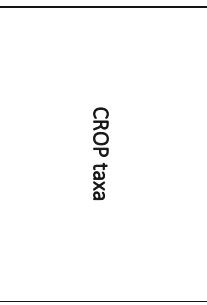 & 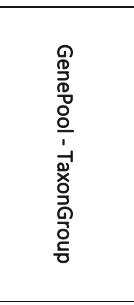 & 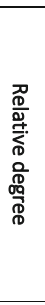 & 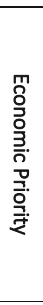 & 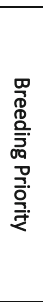 & 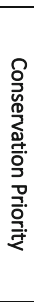 & 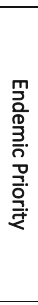 & 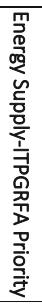 & 态 & 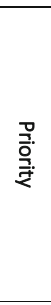 \\
\hline POACEAE & Aegilops cylindrica Host & species & $\sum_{D}^{n}$ & & Wheat & Triticum aestivum L. & GenePool & 2 & 10 & 6 & 0 & 0 & 10 & 5.2 & High \\
\hline POACEAE & $\begin{array}{l}\text { Aegilops geniculata Roth subsp. } \\
\text { geniculata }\end{array}$ & subsp. & $\sum_{\infty}^{n}$ & & Wheat & Triticum aestivum L. & GenePool & 2 & 10 & 6 & 2 & 0 & 10 & 5.6 & High \\
\hline POACEAE & $\begin{array}{l}\text { Aegilops geniculata subsp. africana } \\
\text { (Eig) H. Scholz }\end{array}$ & subsp. & $\sum_{\infty}^{n}$ & & Wheat & Triticum aestivum L. & GenePool & 2 & 10 & 6 & 0 & 0 & 10 & 5.2 & High \\
\hline POACEAE & Aegilops kotschyi Boiss. & species & $\sum_{D}^{\bigcap}$ & & Wheat & Triticum aestivum L. & GenePool & 2 & 10 & 6 & 2 & 0 & 10 & 5.6 & High \\
\hline POACEAE & $\begin{array}{l}\text { Aegilops neglecta Bertol. subsp. } \\
\text { neglecta }\end{array}$ & subsp. & $\sum_{D}^{n}$ & & Wheat & Triticum aestivum L. & GenePool & 2 & 10 & 6 & 2 & 0 & 10 & 5.6 & High \\
\hline POACEAE & Aegilops subulata Pomel & species & $\sum_{D}^{n}$ & & Wheat & Triticum aestivum L. & GenePool & 2 & 10 & 6 & 0 & 0 & 10 & 5.2 & High \\
\hline POACEAE & $\begin{array}{l}\text { Aegilops triuncialis L. subsp. } \\
\text { triuncialis }\end{array}$ & subsp. & $\sum_{D}^{n}$ & & Wheat & Triticum aestivum L. & GenePool & 2 & 10 & 6 & 2 & 0 & 10 & 5.6 & High \\
\hline POACEAE & Aegilops ventricosa Tausch & species & $\sum_{\infty}^{n}$ & & Wheat & Triticum aestivum L. & GenePool & 2 & 10 & 6 & 2 & 0 & 10 & 5.6 & High \\
\hline ALLIACEAE & $\begin{array}{l}\text { Allium ampeloprasum L. subsp. } \\
\text { ampeloprasum }\end{array}$ & subsp. & $\sum_{D}^{\bigcap}$ & 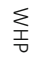 & Leek & Allium porrum L. & GenePool & $1 b$ & 10 & 10 & 0 & 0 & 10 & 6 & High \\
\hline ALLIACEAE & $\begin{array}{l}\text { Allium chamaemoly L. subsp. } \\
\text { chamaemoly }\end{array}$ & subsp. & $\sum_{D}^{\bigcap}$ & 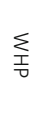 & $\begin{array}{l}\text { Leeks and } \\
\text { other } \\
\text { alliaceous } \\
\text { vegetables }\end{array}$ & Allium sp. pl. & TaxonGroup & 4 & 10 & 4 & 2 & 0 & 10 & 5.2 & High \\
\hline ALLIACEAE & Allium commutatum Guss. & species & $\sum_{D}^{\bigcap}$ & & Leek & Allium porrum L. & GenePool & $1 b$ & 10 & 10 & 2 & 0 & 10 & 6.4 & High \\
\hline ALLIACEAE & $\begin{array}{l}\text { Allium porrum subsp. polyanthum } \\
\text { (Schult. \& Schult. f.) Jauzein \& J.-M. } \\
\text { Tison }\end{array}$ & subsp. & $\sum_{\infty}^{n}$ & $\sum_{\substack{I \\
0}}$ & Leek & Allium porrum L. & GenePool & $1 b$ & 10 & 10 & 0 & 0 & 10 & 6 & High \\
\hline ALLIACEAE & Allium tourneuxii Chabert & species & $\sum_{D}^{\bigcap}$ & & $\begin{array}{l}\text { Leeks and } \\
\text { other } \\
\text { alliaceous } \\
\text { vegetables }\end{array}$ & Allium sp. pl. & TaxonGroup & 4 & 10 & 4 & 0 & 10 & 10 & 6.8 & High \\
\hline ALLIACEAE & Allium triquetrum $\mathrm{L}$. & species & $\sum_{D}^{n}$ & 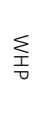 & $\begin{array}{l}\text { Leeks and } \\
\text { other } \\
\text { alliaceous } \\
\text { vegetables }\end{array}$ & Allium sp.pl. & TaxonGroup & 4 & 10 & 4 & 2 & 0 & 10 & 5.2 & High \\
\hline AMARANTHACEAE & Amaranthus cruentus L. & species & $\sum_{D}^{\bigcap}$ & & $\begin{array}{l}\text { Amaranth, } \\
\text { Purple }\end{array}$ & $\begin{array}{l}\text { Amaranthus } \\
\text { cruentus L. }\end{array}$ & GenePool & $1 b$ & 10 & 10 & 0 & 0 & 10 & 6 & High \\
\hline APIACEAE & Anethum graveolens L. & species & $\sum_{D}^{\bigcap}$ & 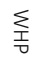 & Dill Seed & $\begin{array}{c}\text { Anethum graveolens } \\
\mathrm{L} \text {. }\end{array}$ & TaxonGroup & $1 b$ & 8 & 10 & 0 & 0 & 10 & 5.6 & High \\
\hline APIACEAE & Anthriscus cerefolium (L.) Hoffm. & species & $\sum_{D}^{n}$ & & Chervil & $\begin{array}{l}\text { Anthriscus } \\
\text { cerefolium (L.) } \\
\text { Hoffm. }\end{array}$ & TaxonGroup & $1 b$ & 10 & 10 & 0 & 0 & 10 & 6 & High \\
\hline APIACEAE & Apium graveolens $\mathrm{L}$. & species & $\sum_{D}^{n}$ & 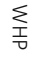 & Celery & Apium graveolens $\mathrm{L}$. & GenePool & $1 b$ & 10 & 10 & 2 & 0 & 10 & 6.4 & High \\
\hline ERICACEAE & Arbutus unedo L. & species & $\sum_{D}^{n}$ & 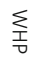 & $\begin{array}{l}\text { Tree- } \\
\text { Strawberry }\end{array}$ & Arbutus unedo L. & TaxonGroup & $1 b$ & 10 & 10 & 2 & 0 & 10 & 6.4 & High \\
\hline ASTERACEAE & Artemisia atlantica Coss. & species & $\sum_{j}^{n}$ & 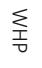 & Tarragon & $\begin{array}{c}\text { Artemisia } \\
\text { dracunculus L. }\end{array}$ & TaxonGroup & 4 & 10 & 4 & 0 & 10 & 10 & 6.8 & High \\
\hline ASTERACEAE & $\begin{array}{l}\text { Artemisia campestris subsp. } \\
\text { cinerea Le Houér. }\end{array}$ & subsp. & $\sum_{D}^{n}$ & 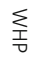 & Tarragon & $\begin{array}{c}\text { Artemisia } \\
\text { dracunculus L. }\end{array}$ & TaxonGroup & 4 & 10 & 4 & 0 & 10 & 10 & 6.8 & High \\
\hline ASTERACEAE & Artemisia saharae Pomel & species & $\sum_{D}^{n}$ & $\sum_{\substack{0 \\
0}}$ & Tarragon & $\begin{array}{c}\text { Artemisia } \\
\text { dracunculus L. }\end{array}$ & TaxonGroup & 4 & 10 & 4 & 0 & 10 & 10 & 6.8 & High \\
\hline
\end{tabular}


Table 4 continued

\begin{tabular}{|c|c|c|c|c|c|c|c|c|c|c|c|c|c|c|c|}
\hline 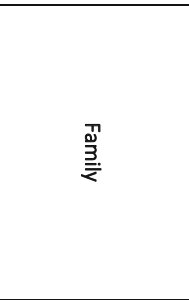 & 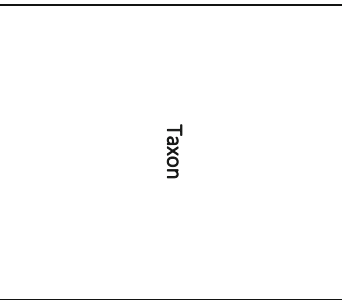 & 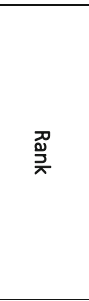 & $\sum_{D}^{n}$ & $\underset{\text { I }}{\text { I }}$ & 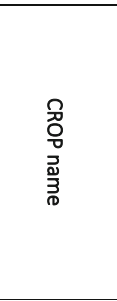 & 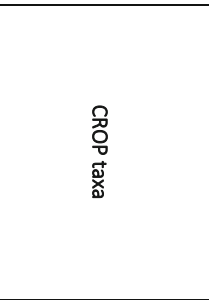 & 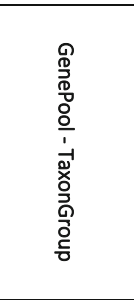 & 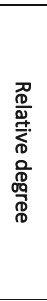 & 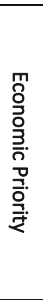 & 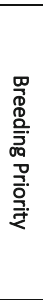 & 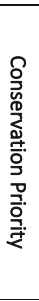 & 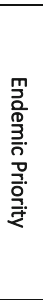 & 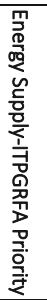 & 忍 & 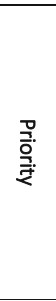 \\
\hline ASPARAGACEAE & Asparagus officinalis L. & species & $\sum_{D}^{\bigcap}$ & $\sum_{\substack{T \\
0}}$ & Asparagus & $\begin{array}{c}\text { Asparagus officinalis } \\
\mathrm{L} \text {. }\end{array}$ & GenePool & $1 b$ & 5 & 10 & 2 & 0 & 10 & 5.4 & High \\
\hline FABACEAE & Astragalus falciformis Desf. & species & $\sum_{D}^{n}$ & & Milkvetch & Astragalus sp. pl. & TaxonGroup & 4 & 0 & 4 & 4 & 10 & 10 & 5.6 & High \\
\hline FABACEAE & Astragalus saharae Pomel & species & $\sum_{j}^{n}$ & & Milkvetch & Astragalus sp.pl. & TaxonGroup & 4 & 0 & 4 & 4 & 10 & 10 & 5.6 & High \\
\hline AMARANTHACEAE & $\begin{array}{l}\text { Atriplex halimus var. schweinfurthii } \\
\text { Boiss. }\end{array}$ & var. & $\sum_{\infty}^{n}$ & 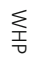 & $\begin{array}{l}\text { Orach } \\
\text { Spinach }\end{array}$ & Atriplex hortensis L. & TaxonGroup & 4 & 10 & 4 & 4 & 0 & 10 & 5.6 & High \\
\hline AMARANTHACEAE & Atriplex mollis Desf. & species & $\sum_{j}^{n}$ & & $\begin{array}{l}\text { Orach } \\
\text { Spinach }\end{array}$ & Atriplex hortensis L. & TaxonGroup & 4 & 10 & 4 & 4 & 10 & 10 & 7.6 & High \\
\hline POACEAE & Avena fatua L. subsp. fatua & subsp. & $\sum_{j}^{n}$ & & Oat & Avena sativa $\mathrm{L}$. & GenePool & $1 b$ & 5 & 10 & 2 & 0 & 10 & 5.4 & High \\
\hline POACEAE & Avena sativa L. subsp. sativa & subsp. & $\sum_{j}^{\bigcap}$ & $\sum_{\substack{T \\
0}}$ & Oat & Avena sativa $\mathrm{L}$. & GenePool & $1 b$ & 5 & 10 & 0 & 0 & 10 & 5 & High \\
\hline POACEAE & Avena sterilis L. subsp. sterilis & subsp. & $\sum_{D}^{n}$ & & Oat & Avena sativa $\mathrm{L}$. & GenePool & $1 b$ & 5 & 10 & 2 & 0 & 10 & 5.4 & High \\
\hline POACEAE & $\begin{array}{l}\text { Avena sterilis subsp. atherantha (C. } \\
\text { Presl) H. Scholz }\end{array}$ & subsp. & $\sum_{D}^{\bigcap}$ & & Oat & Avena sativa $\mathrm{L}$. & GenePool & $1 b$ & 5 & 10 & 0 & 0 & 10 & 5 & High \\
\hline POACEAE & $\begin{array}{l}\text { Avena sterilis subsp. Iudoviciana } \\
\text { (Durieu) Gillet \& Magne }\end{array}$ & subsp. & $\sum_{j 0}^{n}$ & & Oat & Avena sativa $\mathrm{L}$. & GenePool & $1 b$ & 5 & 10 & 0 & 0 & 10 & 5 & High \\
\hline AMARANTHACEAE & Beta macrocarpa Guss. & species & $\sum_{\infty}^{n}$ & $\sum_{\substack{T \\
T}}$ & Sugarbeet & Beta vulgaris $\mathrm{L}$. & GenePool & $1 b$ & 5 & 10 & 0 & 0 & 10 & 5 & High \\
\hline AMARANTHACEAE & $\begin{array}{l}\text { Beta vulgaris subsp. maritima (L.) } \\
\text { Arcang. }\end{array}$ & subsp. & $\sum_{D}^{n}$ & 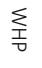 & Sugarbeet & Beta vulgaris $\mathrm{L}$. & GenePool & $1 b$ & 5 & 10 & 0 & 0 & 10 & 5 & High \\
\hline BRASSICACEAE & Brassica insularis Moris & species & $\sum_{j}^{n}$ & & $\begin{array}{l}\text { Cabbage- } \\
\text { Kale }\end{array}$ & Brassica oleracea $\mathrm{L}$. & GenePool & 2 & 10 & 6 & 4 & 10 & 10 & 8 & High \\
\hline BRASSICACEAE & Brassica juncea (L.) Czern. & species & $\sum_{D}^{n}$ & & Mustard & $\begin{array}{l}\text { Brassica juncea (L.) } \\
\text { Czern. }\end{array}$ & GenePool & $1 b$ & 10 & 10 & 0 & 0 & 10 & 6 & High \\
\hline BRASSICACEAE & Brassica nigra (L.) W.D.J. Koch & species & $\sum_{D}^{n}$ & & $\begin{array}{l}\text { Mustard- } \\
\text { Black }\end{array}$ & $\begin{array}{l}\text { Brassica nigra (L.) } \\
\text { W.D.J. Koch }\end{array}$ & GenePool & $1 b$ & 10 & 10 & 0 & 0 & 10 & 6 & High \\
\hline BRASSICACEAE & Brassica oleracea L. & species & $\sum_{D}^{n}$ & 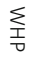 & $\begin{array}{l}\text { Cabbage- } \\
\text { Kale }\end{array}$ & Brassica oleracea $\mathrm{L}$. & GenePool & $1 b$ & 10 & 10 & 0 & 0 & 10 & 6 & High \\
\hline BRASSICACEAE & Brassica rapa L. subsp. rapa & subsp. & $\sum_{j}^{n}$ & 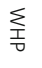 & Turnip & Brassica rapa $\mathrm{L}$. & GenePool & $1 b$ & 10 & 10 & 0 & 0 & 10 & 6 & High \\
\hline BRASSICACEAE & $\begin{array}{l}\text { Brassica rapa subsp. campestris } \\
\text { (L.) A. R. Clapham }\end{array}$ & subsp. & $\sum_{D}^{n}$ & & Turnip & Brassica rapa $\mathrm{L}$. & GenePool & $1 b$ & 10 & 10 & 0 & 0 & 10 & 6 & High \\
\hline BRASSICACEAE & Brassica tournefortii Gouan & species & $\sum_{j}^{n}$ & 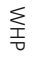 & $\begin{array}{l}\text { Cabbage- } \\
\text { Kale }\end{array}$ & Brassica oleracea $\mathrm{L}$. & GenePool & 2 & 10 & 6 & 0 & 0 & 10 & 5.2 & High \\
\hline CAPPARACEAE & Capparis spinosa L. subsp. spinosa & subsp. & $\sum_{D}^{n}$ & 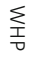 & Capers & Capparis spinosa L. & TaxonGroup & $1 b$ & 10 & 10 & 0 & 0 & 10 & 6 & High \\
\hline CAESALPINIACEAE & Ceratonia siliqua L. & species & $\sum_{D}^{n}$ & 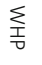 & Carob & Ceratonia siliqua L. & TaxonGroup & $1 b$ & 5 & 10 & 4 & 0 & 10 & 5.8 & High \\
\hline FABACEAE & Cicer arietinum L. & species & $\sum_{D}^{n}$ & 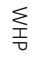 & Chickpea & Cicer arietinum L. & GenePool & $1 b$ & 10 & 10 & 0 & 0 & 10 & 6 & High \\
\hline ASTERACEAE & Cichorium intybus L. & species & $\sum_{D}^{\bigcap}$ & $\underset{⿱}{\underline{T}}$ & Chicory & Cichorium intybus L. & GenePool & $1 b$ & 10 & 10 & 0 & 0 & 10 & 6 & High \\
\hline ASTERACEAE & Cichorium pumilum Jacq. & species & $\sum_{j}^{n}$ & 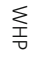 & Endive & Cichorium endivia $\mathrm{L}$. & GenePool & $1 b$ & 10 & 10 & 0 & 0 & 10 & 6 & High \\
\hline
\end{tabular}


Table 4 continued

\begin{tabular}{|c|c|c|c|c|c|c|c|c|c|c|c|c|c|c|c|}
\hline 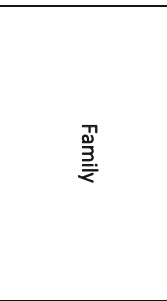 & 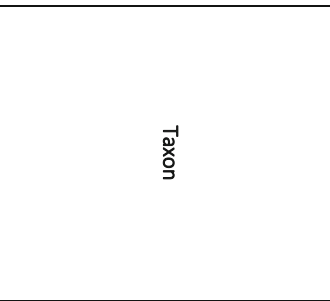 & 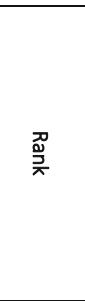 & $\sum_{D}^{n}$ & $\underset{⿱ ㇒ 士}{Ð}$ & 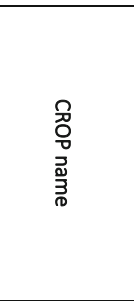 & 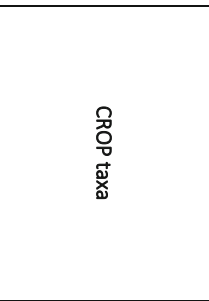 & 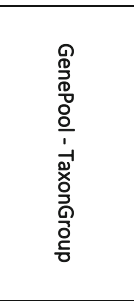 & 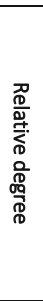 & 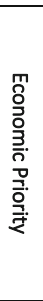 & 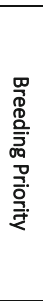 & 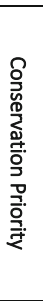 & 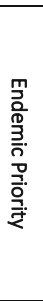 & 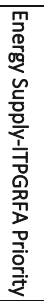 & 忍 & 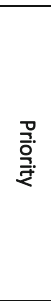 \\
\hline CUCURBITACEAE & Citrullus colocynthis (L.) Schrad. & species & $\sum_{D}^{n}$ & 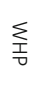 & Watermelon & $\begin{array}{c}\text { Citrullus lanatus } \\
\text { (Thunb.) Matsum. \& } \\
\text { Nakai. }\end{array}$ & GenePool & 2 & 10 & 6 & 0 & 0 & 10 & 5.2 & High \\
\hline APIACEAE & Coriandrum sativum L. & species & $\sum_{D}^{n}$ & 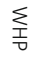 & Coriander & $\begin{array}{c}\text { Coriandrum sativum } \\
\text { L. }\end{array}$ & TaxonGroup & $1 b$ & 10 & 10 & 0 & 0 & 10 & 6 & High \\
\hline ROSACEAE & Crataegus azarolus L. & species & $\sum_{D}^{\bigcap}$ & 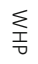 & Azarole & $\begin{array}{c}\text { Crataegus azarolus } \\
\mathrm{L} .\end{array}$ & TaxonGroup & $1 b$ & 10 & 10 & 2 & 0 & 10 & 6.4 & High \\
\hline ROSACEAE & Crataegus laciniata Ucria & species & $\sum_{D}^{n}$ & 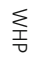 & Azarole & $\begin{array}{c}\text { Crataegus azarolus } \\
\text { L. }\end{array}$ & TaxonGroup & 4 & 10 & 4 & 2 & 0 & 10 & 5.2 & High \\
\hline ROSACEAE & Crataegus monogyna Jacq. & species & $\sum_{D}^{n}$ & 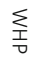 & Azarole & $\begin{array}{c}\text { Crataegus azarolus } \\
\text { L. }\end{array}$ & TaxonGroup & 4 & 10 & 4 & 2 & 0 & 10 & 5.2 & High \\
\hline CUCURBITACEAE & Cucumis melo L. & species & $\sum_{D}^{n}$ & $\sum_{\substack{I\\
}}$ & Melon & Cucumis melo L. & GenePool & $1 b$ & 10 & 10 & 0 & 0 & 10 & 6 & High \\
\hline APIACEAE & Cuminum cyminum L. & species & $\sum_{j}^{n}$ & 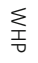 & Cumin & $\begin{array}{c}\text { Cuminum cyminum } \\
\mathrm{L} .\end{array}$ & TaxonGroup & $1 b$ & 10 & 10 & 0 & 0 & 10 & 6 & High \\
\hline ASTERACEAE & $\begin{array}{l}\text { Cynara cardunculus L. subsp. } \\
\text { cardunculus }\end{array}$ & subsp. & $\sum_{D}^{n}$ & 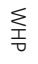 & Artichoke & $\begin{array}{c}\text { Cynara cardunculus } \\
\text { L. }\end{array}$ & GenePool & $1 b$ & 10 & 10 & 0 & 0 & 10 & 6 & High \\
\hline ASTERACEAE & $\begin{array}{l}\text { Cynara cardunculus subsp. } \\
\text { flavescens Wiklund }\end{array}$ & subsp. & $\sum_{D}^{\bigcap}$ & 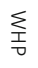 & Artichoke & $\begin{array}{c}\text { Cynara cardunculus } \\
\text { L. }\end{array}$ & GenePool & $1 b$ & 10 & 10 & 0 & 0 & 10 & 6 & High \\
\hline POACEAE & $\begin{array}{l}\text { Dactylis glomerata subsp. santai } \\
\text { Stebbins \& D. Zohary }\end{array}$ & subsp. & $\sum_{j}^{n}$ & & $\begin{array}{l}\text { Orchard } \\
\text { Grass }\end{array}$ & Dactylis glomerata L. & TaxonGroup & $1 b$ & 0 & 10 & 0 & 10 & 10 & 6 & High \\
\hline APIACEAE & Daucus carota L. subsp. carota & subsp. & $\sum_{j}^{n}$ & $\underset{\substack{I \\
0}}{\sum}$ & Carrot & Daucus carota $\mathrm{L}$. & GenePool & $1 b$ & 10 & 10 & 0 & 0 & 10 & 6 & High \\
\hline APIACEAE & $\begin{array}{l}\text { Daucus carota subsp. drepanensis } \\
\text { (Lojac.) Heywood }\end{array}$ & subsp. & $\sum_{X}^{n}$ & & Carrot & Daucus carota $\mathrm{L}$. & GenePool & $1 b$ & 10 & 10 & 0 & 0 & 10 & 6 & High \\
\hline APIACEAE & $\begin{array}{l}\text { Daucus carota subsp. fontanesii } \\
\text { Thell. }\end{array}$ & subsp. & $\sum_{j}^{n}$ & & Carrot & Daucus carota $\mathrm{L}$. & GenePool & $1 b$ & 10 & 10 & 0 & 0 & 10 & 6 & High \\
\hline APIACEAE & $\begin{array}{l}\text { Daucus carota subsp. hispanicus } \\
\text { (Gouan) Thell. }\end{array}$ & subsp. & $\sum_{D}^{\bigcap}$ & & Carrot & Daucus carota $\mathrm{L}$. & GenePool & $1 b$ & 10 & 10 & 0 & 0 & 10 & 6 & High \\
\hline APIACEAE & $\begin{array}{l}\text { Daucus carota subsp. maritimus } \\
\text { (Lam.) Batt. }\end{array}$ & subsp. & $\sum_{j}^{n}$ & 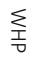 & Carrot & Daucus carota $\mathrm{L}$. & GenePool & $1 b$ & 10 & 10 & 0 & 0 & 10 & 6 & High \\
\hline APIACEAE & $\begin{array}{l}\text { Daucus carota subsp. maximus } \\
\text { (Desf.) Ball }\end{array}$ & subsp. & $\sum_{\infty}^{n}$ & & Carrot & Daucus carota $\mathrm{L}$. & GenePool & $1 b$ & 10 & 10 & 0 & 0 & 10 & 6 & High \\
\hline APIACEAE & $\begin{array}{l}\text { Daucus carota subsp. sativus } \\
\text { Schübl. \& G. Martens }\end{array}$ & subsp. & $\sum_{D}^{\bigcap}$ & 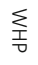 & Carrot & Daucus carota $\mathrm{L}$. & GenePool & $1 b$ & 10 & 10 & 0 & 0 & 10 & 6 & High \\
\hline APIACEAE & Daucus durieua Lange & species & $\sum_{D}^{n}$ & & Carrot & Daucus carota $\mathrm{L}$. & TaxonGroup & 4 & 10 & 4 & 2 & 0 & 10 & 5.2 & High \\
\hline APIACEAE & Daucus reboudii Coss. ex Batt. & species & $\sum_{D}^{n}$ & & Carrot & Daucus carota $\mathrm{L}$. & TaxonGroup & 4 & 10 & 4 & 0 & 10 & 10 & 6.8 & High \\
\hline APIACEAE & Daucus rouyi Spalik \& Reduron & species & $\sum_{\infty}^{n}$ & & Carrot & Daucus carota $\mathrm{L}$. & GenePool & 2 & 10 & 6 & 0 & 0 & 10 & 5.2 & High \\
\hline APIACEAE & Daucus sahariensis Murb. & species & $\sum_{x}^{2}$ & & Carrot & Daucus carota $\mathrm{L}$. & GenePool & 2 & 10 & 6 & 2 & 0 & 10 & 5.6 & High \\
\hline APIACEAE & Daucus syrticus Murb. & species & $\sum_{D}^{n}$ & & Carrot & Daucus carota $\mathrm{L}$. & GenePool & $1 b$ & 10 & 10 & 0 & 10 & 10 & 8 & High \\
\hline APIACEAE & Daucus virgatus (Poir.) Maire & species & $\sum_{x}^{n}$ & & Carrot & Daucus carota L. & GenePool & $1 b$ & 10 & 10 & 0 & 10 & 10 & 8 & High \\
\hline BRASSICACEAE & Diplotaxis simplex (Viv.) Spreng. & species & $\sum_{D}^{n}$ & 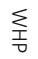 & $\begin{array}{c}\text { Perennial } \\
\text { Wall Rocket }\end{array}$ & $\begin{array}{l}\text { Diplotaxis tenuifolia } \\
\text { (L.) DC. }\end{array}$ & TaxonGroup & 4 & 10 & 4 & 0 & 10 & 10 & 6.8 & High \\
\hline
\end{tabular}


Table 4 continued

\begin{tabular}{|c|c|c|c|c|c|c|c|c|c|c|c|c|c|c|c|}
\hline 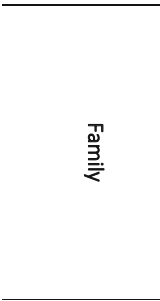 & $\begin{array}{l}\stackrel{-1}{\ddot{x}} \\
\text { 을 }\end{array}$ & 뀸 & $\sum_{D}^{n}$ & 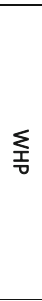 & 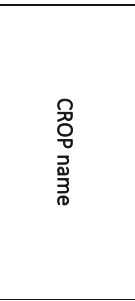 & 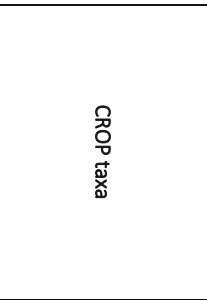 & 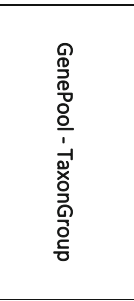 & 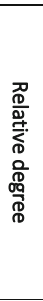 & 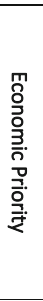 & 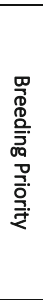 & 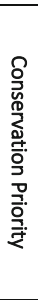 & 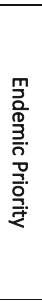 & 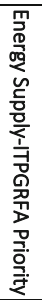 & 忍 & 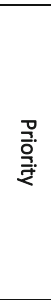 \\
\hline MORACEAE & Ficus carica L. subsp. carica & subsp. & $\sum_{D}^{2}$ & 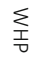 & Fig & Ficus carica L. & GenePool & $1 b$ & 10 & 10 & 0 & 0 & 10 & 6 & High \\
\hline APIACEAE & $\begin{array}{l}\text { Foeniculum vulgare Mill. subsp. } \\
\text { vulgare }\end{array}$ & subsp. & $\sum_{0}^{\bigcap}$ & 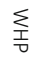 & Fennel & $\begin{array}{l}\text { Foeniculum vulgare } \\
\text { Mill. }\end{array}$ & TaxonGroup & $1 b$ & 10 & 10 & 0 & 0 & 10 & 6 & High \\
\hline APIACEAE & $\begin{array}{l}\text { Foeniculum vulgare subsp. } \\
\text { piperitum (Ucria) Bég. }\end{array}$ & subsp. & $\sum_{D}^{n}$ & 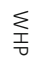 & Fennel & $\begin{array}{l}\text { Foeniculum vulgare } \\
\text { Mill. }\end{array}$ & TaxonGroup & $1 b$ & 10 & 10 & 0 & 0 & 10 & 6 & High \\
\hline MALVACEAE & Gossypium herbaceum L. & species & $\sum_{D}^{\bigcap}$ & 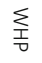 & Tree Cotton & $\begin{array}{l}\text { Gossypium } \\
\text { arboreum L. }\end{array}$ & GenePool & 2 & 10 & 6 & 0 & 0 & 10 & 5.2 & High \\
\hline BRASSICACEAE & $\begin{array}{l}\text { Guenthera dimorpha (Coss. \& } \\
\text { Durieu) Gómez-Campo }\end{array}$ & species & $\sum_{D}^{n}$ & & Rape & Brassica napus L. & GenePool & 3 & 9 & 2 & 0 & 10 & 10 & 6.2 & High \\
\hline CUPRESSACEAE & $\begin{array}{l}\text { Juniperus oxycedrus L. subsp. } \\
\text { oxycedrus }\end{array}$ & subsp. & $\sum_{D}^{n}$ & & $\begin{array}{l}\text { Juniper } \\
\text { Berries }\end{array}$ & $\begin{array}{l}\text { Juniperus communis } \\
\text { L. }\end{array}$ & TaxonGroup & 4 & 10 & 4 & 4 & 0 & 10 & 5.6 & High \\
\hline CUPRESSACEAE & $\begin{array}{l}\text { Juniperus phoenicea L. subsp. } \\
\text { phoenicea }\end{array}$ & subsp. & $\sum_{D}^{n}$ & 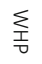 & $\begin{array}{l}\text { Juniper } \\
\text { Berries }\end{array}$ & $\begin{array}{c}\text { Juniperus communis } \\
\text { L. }\end{array}$ & TaxonGroup & 4 & 10 & 4 & 4 & 0 & 10 & 5.6 & High \\
\hline FABACEAE & Lablab purpureus (L.) Sweet & species & $\sum_{D}^{\bigcap}$ & 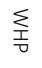 & $\begin{array}{l}\text { Hyacinth } \\
\text { Bean }\end{array}$ & $\begin{array}{l}\text { Lablab purpureus } \\
\text { (L.) Sweet }\end{array}$ & GenePool & $1 b$ & 10 & 10 & 0 & 0 & 10 & 6 & High \\
\hline ASTERACEAE & Lactuca saligna L. & species & $\sum_{D}^{n}$ & & Lettuce & Lactuca sativa L. & GenePool & 2 & 10 & 6 & 0 & 0 & 10 & 5.2 & High \\
\hline ASTERACEAE & Lactuca serriola L. & species & $\sum_{D}^{\bigcap}$ & & Lettuce & Lactuca sativa $\mathrm{L}$. & GenePool & $1 b$ & 10 & 10 & 0 & 0 & 10 & 6 & High \\
\hline FABACEAE & Lathyrus brachyodon Murb. & species & $\sum_{D}^{n}$ & & Grass-Pea & Lathyrus sativus L. & TaxonGroup & 4 & 0 & 4 & 4 & 10 & 10 & 5.6 & High \\
\hline LAURACEAE & Laurus nobilis L. & species & $\sum_{D}^{n}$ & 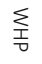 & Laurel & Laurus nobilis L. & TaxonGroup & $1 b$ & 8 & 10 & 2 & 0 & 10 & 6 & High \\
\hline FABACEAE & Lens culinaris Medik. & species & $\sum_{D}^{2}$ & $\sum_{\substack{I \\
0}}$ & Lentil & Lens culinaris Medik. & GenePool & $1 b$ & 8 & 10 & 0 & 0 & 10 & 5.6 & High \\
\hline BRASSICACEAE & Lepidium glastifolium Desf. & species & $\sum_{D}^{n}$ & & $\begin{array}{l}\text { Garden } \\
\text { Cress }\end{array}$ & Lepidium sativum $\mathrm{L}$. & TaxonGroup & 4 & 10 & 4 & 0 & 10 & 10 & 6.8 & High \\
\hline BRASSICACEAE & Lepidium sativum L. subsp. sativum & subsp. & $\sum_{D}^{n}$ & 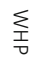 & $\begin{array}{l}\text { Garden } \\
\text { Cress }\end{array}$ & Lepidium sativum $\mathrm{L}$. & GenePool & $1 b$ & 10 & 10 & 0 & 0 & 10 & 6 & High \\
\hline LINACEAE & Linum bienne Mill. & species & $\sum_{D}^{n}$ & 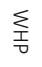 & Flax & $\begin{array}{l}\text { Linum usitatissimum } \\
\text { L. }\end{array}$ & GenePool & $1 b$ & 8 & 10 & 0 & 0 & 10 & 5.6 & High \\
\hline LINACEAE & $\begin{array}{l}\text { Linum corymbiferum subsp. } \\
\text { aristidis (Batt.) Batt. }\end{array}$ & subsp. & $\sum_{\infty}^{n}$ & & Flax & $\begin{array}{l}\text { Linum usitatissimum } \\
\text { L. }\end{array}$ & TaxonGroup & 4 & 8 & 4 & 0 & 10 & 10 & 6.4 & High \\
\hline LINACEAE & $\begin{array}{l}\text { Linum corymbiferum subsp. } \\
\text { asperifolium (Boiss. \& Reut.) } \\
\text { Martínez }\end{array}$ & subsp. & $\sum_{D}^{\infty}$ & & Flax & $\begin{array}{l}\text { Linum usitatissimum } \\
\text { L. }\end{array}$ & TaxonGroup & 4 & 8 & 4 & 0 & 10 & 10 & 6.4 & High \\
\hline LINACEAE & Linum usitatissimum L. & species & $\sum_{\infty}^{\bigcap}$ & 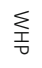 & Flax & $\begin{array}{l}\text { Linum usitatissimum } \\
\text { L. }\end{array}$ & GenePool & $1 b$ & 8 & 10 & 0 & 0 & 10 & 5.6 & High \\
\hline ROSACEAE & Malus pumila Mill. & species & $\sum_{D}^{n}$ & 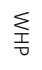 & Apple & $\begin{array}{l}\text { Malus domestica } \\
\text { Borkh. }\end{array}$ & GenePool & 2 & 10 & 6 & 0 & 0 & 10 & 5.2 & High \\
\hline OLEACEAE & Olea europaea L. subsp. europaea & subsp. & $\sum_{\infty}^{n}$ & $\sum_{\substack{I \\
0}}$ & Olive & Olea europaea $\mathrm{L}$. & GenePool & $1 b$ & 10 & 10 & 4 & 0 & 10 & 6.8 & High \\
\hline CACTACEAE & Opuntia ficus-indica (L.) Mill. & species & $\sum_{j}^{n}$ & 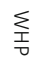 & Indian Fig & $\begin{array}{l}\text { Opuntia ficus-indica } \\
\text { (L.) Mill. }\end{array}$ & TaxonGroup & $1 b$ & 10 & 10 & 0 & 0 & 10 & 6 & High \\
\hline APIACEAE & $\begin{array}{l}\text { Petroselinum crispum (Mill.) Fuss } \\
\text { subsp. crispum }\end{array}$ & subsp. & $\sum_{j}^{n}$ & & Parsley & $\begin{array}{l}\text { Petroselinum } \\
\text { crispum (Mill.) Fuss }\end{array}$ & TaxonGroup & $1 b$ & 10 & 10 & 0 & 0 & 10 & 6 & High \\
\hline ARECACEAE & Phoenix dactylifera L. & species & $\sum_{j}^{n}$ & $\sum_{\substack{y \\
\nu}}$ & Date Palm & $\begin{array}{c}\text { Phoenix dactylifera } \\
\text { L. }\end{array}$ & GenePool & $1 b$ & 10 & 10 & 0 & 0 & 10 & 6 & High \\
\hline
\end{tabular}


Table 4 continued

\begin{tabular}{|c|c|c|c|c|c|c|c|c|c|c|c|c|c|c|c|}
\hline 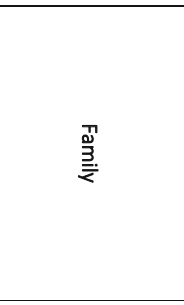 & $\begin{array}{l}\vec{y} \\
\stackrel{1}{3}\end{array}$ & $\begin{array}{l}\text { 뀸 } \\
\stackrel{\Xi}{\vec{x}}\end{array}$ & $\sum_{j}^{n}$ & $\sum_{\substack{T \\
0}}$ & 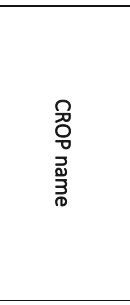 & 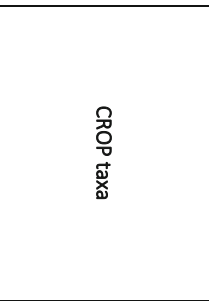 & 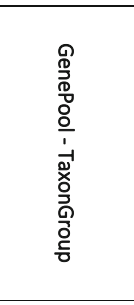 & 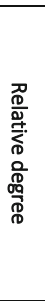 & 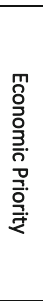 & 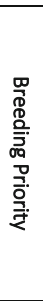 & 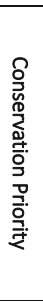 & 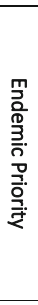 & 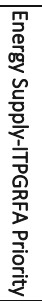 & 忍 & 꼬․ \\
\hline APIACEAE & Pimpinella anisum L. & species & $\sum_{D}^{\infty}$ & $\sum_{\substack{T \\
0}}$ & Anise & Pimpinella anisum L. & TaxonGroup & $1 b$ & 10 & 10 & 0 & 0 & 10 & 6 & High \\
\hline ANACARDIACEAE & Pistacia atlantica Desf. & species & $\sum_{\infty}^{\infty}$ & 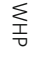 & Pistachio & Pistacia vera $\mathrm{L}$. & GenePool & 2 & 10 & 6 & 4 & 0 & 10 & 6 & High \\
\hline ANACARDIACEAE & Pistacia lentiscus L. & species & $\sum_{\infty}^{\bigcap}$ & 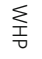 & Pistachio & Pistacia vera $\mathrm{L}$. & GenePool & 2 & 10 & 6 & 4 & 0 & 10 & 6 & High \\
\hline ANACARDIACEAE & Pistacia terebinthus L. & species & $\sum_{j}^{n}$ & & Pistachio & Pistacia vera $\mathrm{L}$. & GenePool & 2 & 10 & 6 & 2 & 0 & 10 & 5.6 & High \\
\hline FABACEAE & $\begin{array}{l}\text { Pisum sativum subsp. elatius (M. } \\
\text { Bieb.) Asch. \& Graebn. }\end{array}$ & subsp. & $\sum_{j}^{n}$ & $\sum_{\substack{T \\
\square}}$ & Pea & Pisum sativum L. & GenePool & $1 b$ & 10 & 10 & 0 & 0 & 10 & 6 & High \\
\hline ROSACEAE & Prunus $\times$ fruticans Weihe & species & $\sum_{\infty}^{n}$ & & Plum & Prunus domestica L. & TaxonGroup & 2 & 10 & 6 & 0 & 0 & 10 & 5.2 & High \\
\hline ROSACEAE & Prunus avium (L.) L. & species & $\sum_{\infty}^{n}$ & $\sum_{\substack{T \\
v}}$ & $\begin{array}{l}\text { Cherry- } \\
\text { Sweet }\end{array}$ & Prunus avium (L.) L. & GenePool & $1 b$ & 10 & 10 & 2 & 0 & 10 & 6.4 & High \\
\hline ROSACEAE & Prunus cerasifera Ehrh. & species & $\sum_{j}^{n}$ & 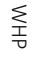 & $\begin{array}{l}\text { Plum- } \\
\text { Myrobalan }\end{array}$ & $\begin{array}{c}\text { Prunus cerasifera } \\
\text { Ehrh. }\end{array}$ & GenePool & $1 b$ & 10 & 10 & 0 & 0 & 10 & 6 & High \\
\hline ROSACEAE & Prunus dulcis (Mill.) D. A. Webb & species & $\sum_{\infty}^{n}$ & $\sum_{\substack{T \\
v}}$ & Almond & $\begin{array}{l}\text { Prunus dulcis (Mill.) } \\
\text { D. A. Webb }\end{array}$ & GenePool & $1 b$ & 10 & 10 & 0 & 0 & 10 & 6 & High \\
\hline ROSACEAE & Prunus insititia L. & species & $\sum_{\lambda}^{n}$ & & $\begin{array}{l}\text { Plum- } \\
\text { European, } \\
\text { Damson }\end{array}$ & Prunus insititia L. & GenePool & $1 b$ & 10 & 10 & 0 & 0 & 10 & 6 & High \\
\hline ROSACEAE & Prunus prostrata Labill. & species & $\sum_{\infty}^{n}$ & & $\begin{array}{l}\text { Plum- } \\
\text { Myrobalan }\end{array}$ & $\begin{array}{c}\text { Prunus cerasifera } \\
\text { Ehrh. }\end{array}$ & GenePool & 2 & 10 & 6 & 2 & 0 & 10 & 5.6 & High \\
\hline ROSACEAE & Prunus spinosa L. & species & $\sum_{D}^{\bigcap}$ & & $\begin{array}{l}\text { Plum- } \\
\text { European }\end{array}$ & Prunus domestica L. & GenePool & 2 & 10 & 6 & 0 & 0 & 10 & 5.2 & High \\
\hline PUNICACEAE & Punica granatum L. & species & $\sum_{j}^{n}$ & 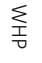 & $\begin{array}{c}\text { Pomegranat } \\
\text { e }\end{array}$ & Punica granatum L. & GenePool & $1 b$ & 10 & 10 & 0 & 0 & 10 & 6 & High \\
\hline ROSACEAE & Pyrus syriaca Boiss. & species & $\sum_{j}^{n}$ & 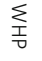 & Pear & Pyrus communis $\mathrm{L}$. & GenePool & 2 & 10 & 6 & 0 & 0 & 10 & 5.2 & High \\
\hline BRASSICACEAE & $\begin{array}{l}\text { Raphanus raphanistrum L. subsp. } \\
\text { raphanistrum }\end{array}$ & subsp. & $\sum_{D}^{n}$ & & Radish & Raphanus sativus L. & GenePool & $1 b$ & 10 & 10 & 0 & 0 & 10 & 6 & High \\
\hline BRASSICACEAE & $\begin{array}{l}\text { Raphanus raphanistrum subsp. } \\
\text { landra (DC.) Bonnier \& Layens }\end{array}$ & subsp. & $\sum_{D}^{\infty}$ & & Radish & Raphanus sativus L. & GenePool & $1 b$ & 10 & 10 & 0 & 0 & 10 & 6 & High \\
\hline BRASSICACEAE & Raphanus sativus L. & species & $\sum_{j}^{n}$ & 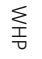 & Radish & Raphanus sativus L. & GenePool & $1 b$ & 10 & 10 & 0 & 0 & 10 & 6 & High \\
\hline POLYGONACEAE & Rumex aristidis Coss. & species & $\sum_{\infty}^{n}$ & & Sorrel & Rumex acetosa L. & TaxonGroup & 4 & 10 & 4 & 0 & 10 & 10 & 6.8 & High \\
\hline POLYGONACEAE & Rumex tunetanus Barratte \& Murb. & species & $\sum_{j}^{n}$ & & Sorrel & Rumex acetosa L. & TaxonGroup & 4 & 10 & 4 & 10 & 10 & 10 & 8.8 & High \\
\hline AMARANTHACEAE & Salsola tunetana Brullo & species & $\sum_{\infty}^{n}$ & & Saltwort & Salsola sp. pl. & TaxonGroup & 4 & 0 & 4 & 4 & 10 & 10 & 5.6 & High \\
\hline CAPRIFOLIACEAE & Sambucus nigra L. & species & $\sum_{j}^{n}$ & 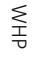 & Elderberry & Sambucus nigra L. & TaxonGroup & $1 b$ & 10 & 10 & 0 & 0 & 10 & 6 & High \\
\hline ASTERACEAE & $\begin{array}{l}\text { Scorzonera hispanica subsp. } \\
\text { coronopifolia (Desf.) Rouy }\end{array}$ & subsp. & $\sum_{j}^{n}$ & & Scorzonera & $\begin{array}{c}\text { Scorzonera hispanica } \\
\text { L. }\end{array}$ & TaxonGroup & $1 b$ & 10 & 10 & 0 & 0 & 10 & 6 & High \\
\hline BRASSICACEAE & $\begin{array}{l}\text { Sinapis alba subsp. dissecta (Lag.) } \\
\text { Bonnier }\end{array}$ & subsp. & $\sum_{j}^{n}$ & & $\begin{array}{l}\text { Mustard- } \\
\text { White }\end{array}$ & Sinapis alba $\mathrm{L}$. & GenePool & $1 b$ & 10 & 10 & 0 & 0 & 10 & 6 & High \\
\hline BRASSICACEAE & $\begin{array}{l}\text { Sinapis alba subsp. mairei }(\mathrm{H} \text {. } \\
\text { Lindb.) Maire }\end{array}$ & subsp. & $\sum_{j}^{n}$ & & $\begin{array}{l}\text { Mustard- } \\
\text { White }\end{array}$ & Sinapis alba $\mathrm{L}$. & GenePool & $1 b$ & 10 & 10 & 0 & 0 & 10 & 6 & High \\
\hline
\end{tabular}


Table 4 continued

\begin{tabular}{|c|c|c|c|c|c|c|c|c|c|c|c|c|c|c|c|}
\hline 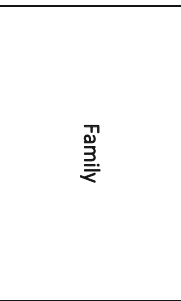 & $\begin{array}{l}\stackrel{1}{\mathfrak{x}} \\
\text { ồ }\end{array}$ & 西 & $\sum_{D}^{\bigcap}$ & $\stackrel{\sum}{\underline{T}}$ & 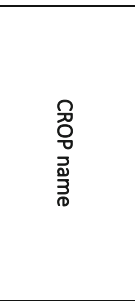 & 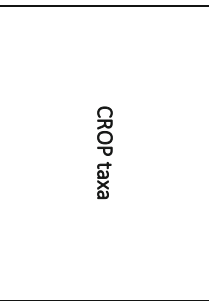 & 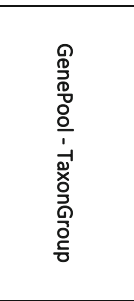 & 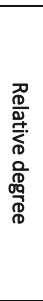 & 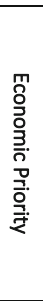 & 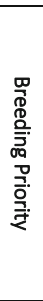 & 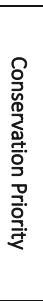 & 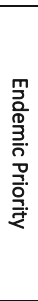 & 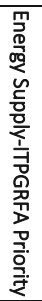 & 忍 & 꼼. \\
\hline BRASSICACEAE & Sinapis arvensis L. subsp. arvensis & subsp. & $\sum_{D}^{\bigcap}$ & & $\begin{array}{l}\text { Mustard- } \\
\text { Black }\end{array}$ & $\begin{array}{l}\text { Brassica nigra (L.) } \\
\text { W.D.J. Koch }\end{array}$ & GenePool & 2 & 10 & 6 & 0 & 0 & 10 & 5.2 & High \\
\hline BRASSICACEAE & $\begin{array}{l}\text { Sinapis pubescens L. subsp. } \\
\text { pubescens }\end{array}$ & subsp. & $\sum_{0}^{\bigcap}$ & & Radish & Raphanus sativus L. & GenePool & 3 & 10 & 2 & 4 & 0 & 10 & 5.2 & High \\
\hline ROSACEAE & Sorbus aria (L.) Crantz & species & $\sum_{\lambda}^{n}$ & & $\begin{array}{l}\text { Service- } \\
\text { Apple }\end{array}$ & Sorbus domestica $\mathrm{L}$. & TaxonGroup & 4 & 10 & 4 & 2 & 0 & 10 & 5.2 & High \\
\hline ROSACEAE & Sorbus umbellata (Desf.) Fritsch & species & $\sum_{D}^{n}$ & & $\begin{array}{l}\text { Service- } \\
\text { Apple }\end{array}$ & Sorbus domestica $\mathrm{L}$. & TaxonGroup & 4 & 10 & 4 & 2 & 0 & 10 & 5.2 & High \\
\hline AMARANTHACEAE & Spinacia oleracea L. & species & $\sum_{D}^{n}$ & 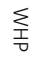 & Spinach & Spinacia oleracea $\mathrm{L}$. & GenePool & $1 b$ & 10 & 10 & 0 & 0 & 10 & 6 & High \\
\hline LAMIACEAE & Thymus algeriensis Boiss. \& Reut. & species & $\sum_{D}^{n}$ & 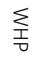 & Thyme & Thymus vulgaris $\mathrm{L}$. & TaxonGroup & 4 & 8 & 4 & 0 & 10 & 10 & 6.4 & High \\
\hline LAMIACEAE & Thymus numidicus Poir. & species & $\sum_{D}^{n}$ & & Thyme & Thymus vulgaris $\mathrm{L}$. & TaxonGroup & 4 & 8 & 4 & 0 & 10 & 10 & 6.4 & High \\
\hline ASTERACEAE & $\begin{array}{l}\text { Tragopogon porrifolius L. subsp. } \\
\text { porrifolius }\end{array}$ & subsp. & $\sum_{D}^{n}$ & & Oyster Plant & $\begin{array}{l}\text { Tragopogon } \\
\text { porrifolius L. }\end{array}$ & TaxonGroup & $1 b$ & 10 & 10 & 0 & 0 & 10 & 6 & High \\
\hline FABACEAE & Trigonella foenum-graecum $\mathrm{L}$. & species & $\sum_{D}^{n}$ & 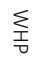 & $\begin{array}{l}\text { Fenugreek } \\
\text { Seed }\end{array}$ & $\begin{array}{l}\text { Trigonella foenum- } \\
\text { graecum L. }\end{array}$ & TaxonGroup & $1 b$ & 8 & 10 & 0 & 0 & 10 & 5.6 & High \\
\hline POACEAE & Triticum dicoccum Schübl. & species & $\sum_{D}^{n}$ & 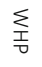 & $\begin{array}{l}\text { Wheat- } \\
\text { Emmer }\end{array}$ & $\begin{array}{l}\text { Triticum dicoccum } \\
\text { Schübl. }\end{array}$ & GenePool & $1 b$ & 10 & 10 & 0 & 0 & 10 & 6 & High \\
\hline POACEAE & Triticum durum Desf. & species & $\sum_{D}^{2}$ & 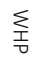 & $\begin{array}{l}\text { Wheat- } \\
\text { Durum }\end{array}$ & Triticum durum Desf. & GenePool & $1 b$ & 10 & 10 & 0 & 0 & 10 & 6 & High \\
\hline POACEAE & Triticum polonicum L. & species & $\sum_{D}^{n}$ & $\sum_{\substack{I \\
0}}$ & $\begin{array}{l}\text { Wheat- } \\
\text { Polish }\end{array}$ & $\begin{array}{c}\text { Triticum polonicum } \\
\text { L. }\end{array}$ & GenePool & $1 b$ & 10 & 10 & 0 & 0 & 10 & 6 & High \\
\hline FABACEAE & Vicia faba L. & species & $\sum_{\lambda}^{n}$ & $\sum_{\substack{T \\
0}}$ & Faba-Bean & Vicia faba L. & GenePool & $1 b$ & 10 & 10 & 0 & 0 & 10 & 6 & High \\
\hline FABACEAE & Vicia fulgens Batt. & species & $\sum_{D}^{n}$ & & $\begin{array}{l}\text { Vetch- } \\
\text { Common }\end{array}$ & Vicia sativa $\mathrm{L}$. & TaxonGroup & 4 & 3 & 4 & 10 & 10 & 10 & 7.4 & High \\
\hline FABACEAE & Vicia monardi Boiss. \& Reut. & species & $\sum_{\lambda}^{n}$ & & Broad beans & Vicia sp. pl. & TaxonGroup & 4 & 10 & 4 & 0 & 10 & 10 & 6.8 & High \\
\hline FABACEAE & Vicia narbonensis $\mathrm{L}$. & species & $\sum_{j}^{\bigcap}$ & & $\begin{array}{l}\text { Vetch- } \\
\text { Narbon }\end{array}$ & Vicia narbonensis L. & GenePool & $1 b$ & 3 & 10 & 2 & 0 & 10 & 5 & High \\
\hline FABACEAE & $\begin{array}{l}\text { Vicia sativa subsp. amphicarpa } \\
\text { (Dorthes) Batt. }\end{array}$ & subsp. & $\sum_{j}^{n}$ & $\sum_{\substack{1 \\
0}}$ & $\begin{array}{l}\text { Vetch- } \\
\text { Common }\end{array}$ & Vicia sativa $\mathrm{L}$. & GenePool & $1 b$ & 3 & 10 & 3 & 0 & 10 & 5.2 & High \\
\hline FABACEAE & $\begin{array}{l}\text { Vicia sativa subsp. macrocarpa } \\
\text { (Moris) Arcang. }\end{array}$ & subsp. & $\sum_{x}^{n}$ & 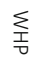 & $\begin{array}{l}\text { Vetch- } \\
\text { Common }\end{array}$ & Vicia sativa $\mathrm{L}$. & GenePool & $1 b$ & 3 & 10 & 2 & 0 & 10 & 5 & High \\
\hline FABACEAE & Vicia sativa subsp. nigra (L.) Ehrh. & subsp. & $\sum_{\lambda}^{n}$ & 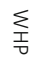 & $\begin{array}{l}\text { Vetch- } \\
\text { Common }\end{array}$ & Vicia sativa $\mathrm{L}$. & GenePool & $1 b$ & 3 & 10 & 2 & 0 & 10 & 5 & High \\
\hline VITACEAE & Vitis vinifera $\mathrm{L}$. subsp. vinifera & subsp. & $\sum_{j}^{n}$ & 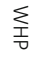 & Grape-Wine & Vitis vinifera $\mathrm{L}$. & GenePool & $1 b$ & 10 & 10 & 0 & 0 & 10 & 6 & High \\
\hline VITACEAE & $\begin{array}{l}\text { Vitis vinifera subsp. sylvestris (C. C. } \\
\text { Gmel.) Hegi }\end{array}$ & subsp. & $\sum_{j}^{n}$ & $\underset{\substack{1 \\
\nu}}{\sum}$ & Grape-Wine & Vitis vinifera $\mathrm{L}$. & GenePool & $1 b$ & 10 & 10 & 0 & 0 & 10 & 6 & High \\
\hline
\end{tabular}


Table 5 Crops/crop groups of high importance with wild relatives in Tunisia

\begin{tabular}{|c|c|c|}
\hline Crop/crop groups & Genus/Genera & No. of high priority taxa \\
\hline Brassicas & Brassica L.; Guenthera Besser; Raphanus L.; Sinapis L & 15 \\
\hline Carrot & Daucus L & 13 \\
\hline Wheat & Aegilops L.; Triticum L & 11 \\
\hline Stonefruits & Prunus L & 7 \\
\hline Broad/horse bean/Vetch & Vicia $\mathrm{L}$ & 7 \\
\hline Leeks and other alliaceous vegetables & Allium $\mathrm{L}$ & 6 \\
\hline Oat & Avena $\mathrm{L}$ & 5 \\
\hline Flax & Linum L & 4 \\
\hline Tarragon & Artemisia L & 3 \\
\hline Azarole & Crataegus $\mathrm{L}$ & 3 \\
\hline Pistachio & Pistacia L & 3 \\
\hline Milkvetch & Astragalus L & 2 \\
\hline Orach Spinach & Atriplex L & 2 \\
\hline Sugarbeet & Beta L & 2 \\
\hline Chicory/Endive & Cichorium $\mathrm{L}$ & 2 \\
\hline Artichoke & Cynara $\mathrm{L}$ & 2 \\
\hline Fennel & Foeniculum Mill & 2 \\
\hline Juniper berries & Juniperus L & 2 \\
\hline Lettuce & Lactuca $\mathrm{L}$ & 2 \\
\hline Garden Cress & Lepidium L & 2 \\
\hline Sorrel & Rumex L & 2 \\
\hline Service-Apple & Sorbus L & 2 \\
\hline Thyme & Thymus L & 2 \\
\hline Grape-Wine & Vitis L & 2 \\
\hline Amaranth, Purple & Amaranthus L & 1 \\
\hline Dill Seed & Anethum L & 1 \\
\hline Chervil & Anthriscus Pers & 1 \\
\hline Celery & Apium $\mathrm{L}$ & 1 \\
\hline Tree-Strawberry & Arbutus L & 1 \\
\hline Asparagus & Asparagus L & 1 \\
\hline Capers & Capparis L & 1 \\
\hline Carob & Ceratonia L & 1 \\
\hline Chickpea & Cicer $\mathrm{L}$ & 1 \\
\hline Watermelon & Citrullus Schrad & 1 \\
\hline Coriander & Coriandrum $\mathrm{L}$ & 1 \\
\hline Melon & Cucumis $\mathrm{L}$ & 1 \\
\hline Cumin & Cитіпит $\mathrm{L}$ & 1 \\
\hline Orchard Grass & Dactylis $\mathrm{L}$ & 1 \\
\hline Perennial Wall Rocket & Diplotaxis DC & 1 \\
\hline Fig & Ficus $\mathrm{L}$ & 1 \\
\hline Tree cotton & Gossypium L & 1 \\
\hline Hyacinth Bean & Lablab Adans & 1 \\
\hline Grass-Pea & Lathyrus L & 1 \\
\hline Laurel & Laurus L & 1 \\
\hline
\end{tabular}


Table 5 continued

\begin{tabular}{llc}
\hline Crop/crop groups & Genus/Genera & No. of high priority taxa \\
\hline Lentil & Lens Mill & 1 \\
Apple & Malus Mill & 1 \\
Olive & Olea L & 1 \\
Indian Fig & Opuntia Mill & 1 \\
Parsley & Petroselinum Hill & 1 \\
date palm & Phoenix L & 1 \\
Anise & Pimpinella L & 1 \\
Pea & Pisum L & 1 \\
Pomegranate & Punica L & 1 \\
Pear & Pyrus L & 1 \\
Saltwort & Salsola L & 1 \\
Elderberry & Sambucus L & 1 \\
Scorzonera & Scorzonera L & 1 \\
Spinach & Spinacia L & 1 \\
Oyster plant & Tragopogon L & 1 \\
Fenugreek seed & Trigonella L & 1 \\
TOTAL & & 1 \\
\hline
\end{tabular}

Maire, together with other 11 taxa of the same genus, are classified as a high priority for further conservation because of their importance for agriculture, their restricted geographical distribution and potential use in breeding for crop improvement. Other taxa, like $D$. aureus Desf., D. crinitus Desf., and D. setifolius Desf., are classified as medium priority because they are less closely related, again in agreement with Mezghani et al. (2019). However, it must be observed that floristic treatments of this genera and the subspecies variation in $D$. carota are often controversial (Mezghani et al. 2017).

Eleven CWR taxa (high priority) belonging to Aegilops L. (GP2) and Triticum L. (GP1b), and 6 tertiary gene pool taxa (medium priority) are relatives of wheat (Triticum spp.) and barley (Hordeum vulgare), respectively - the two most profitable cereal crops in Tunisia. The average wheat production in Tunisia in the period 2012-2016 was 1.2 million tonnes (FAO 2019b), but due to rainfall variations and large inter-annual fluctuations (WFP, 2011), an increasing $(+121 \%)$ wheat import between 1984 and 2016 has been reported (Khaldi and Saaidia 2017; Sadok et al. 2019). Currently, the national production is estimated well below the yield potential of $5 \mathrm{~T}^{\mathrm{ha}^{-1}}$ (ONAGRI 2018). Hence, to ensure yield improvement and food security, the role of these wild relatives could be of great interest for breeding purposes. The same is true also for barley production (Lasram et al. 2017). Citrullus colocynthis (L.) Schrad. (high priority) is the only one CWR for watermelon (Citrullus lanatus (Thunb.) Matsum. and Nakai), another of the most profitable crops. High priority CWR taxa related to other significant Tunisian crops are: Malus pumila Mill., a secondary wild relative of apple, which represents an important economic income for the country (48,5 million US \$ per annum, over the period 2012-2016); Brassica rapa subsp. campestris (L.) A. R. Clapham, primary wild relative of turnip; thirteen Daucus taxa that are primary and secondary wild relatives of carrot-another economically important crop (29 million US \$ per annum, over the period 2012-2016) which contributes, together with turnip, for more than $2 \%$ to the daily energy contribution in Tunisia; Pisum sativum subsp. elatius (M. Bieb.) Asch. and Graebn., primary wild relative of pea, native to the Euro-Mediterranean region and with a potential use against biotic stress (Vincent et al. 2013); and Allium sp. pl. related to onion, leek, and other alliaceous crops, with 6 high and 18 medium priority wild taxa and widely used as food, spices and as medicinal plants. 
It is also worth mentioning the case of olive (Olea europaea L. subsp. europaea). Tunisia is the world's second largest olive oil producer after the EU (IOC, 2021), and olive oil is the main national agricultural product in terms of value, accounting, on average, for about 480 million US \$ per annum (FAO 2019b). Olive oil is the main agricultural export product, its sector represents one of the major drivers for socioeconomic development of the rural areas, and it contributes $1.6 \%$ of the dietary energy per capita per day in the region. The wild form of $O$. europaea L. (GP1b), commonly referred to as Oleaster, has been classified accordingly as high priority. It is still widely used for rootstock, especially in traditional, semi-arid areas of cultivation, and is a suitable genetic resource for crop improvement and for enlarging the basis of genetic variability for olive breeding (Hannachi et al. 2009; Rallo et al. 2018). Therefore, it should be given the highest priority for active in situ and ex situ conservation in Tunisia.

As emerged from this description of the CWR diversity of Tunisia, there are several aspects in which this prioritised plant genetic resources can be useful. At a global level, protecting the biodiversity is fundamental for safeguarding the related ecosystem services which can be beneficial for a more sustainable agriculture. These PGRs can be used to increase food security by improving yield and resistance of the crops to biotic and abiotic factors, and this is particularly true for those wild plant adapted to extreme environmental conditions. This is the case, for example, of the priority CWR related to wheat and barley that could be further investigated in breeding programs aiming at the improvement of yield stability which is strongly affected by environmental factors in the country (Ayed et al. 2021) or carrots and cabbages, which represent a valuable part of the economic income, and are represented by a wide variability of wild relatives in Tunisia.

\section{Conclusions}

Tunisia is not widely recognized as a regional hotspot of plant diversity and endemism (Médail and Quézel 1999) - however, according to several authors, a large part of the country has been included within the Mediterranean biodiversity hotspot for conservation priorities (Vavilov 1926; Myers et al. 2000; Maxted and Vincent 2021). Our results, in agreement with Castañeda-Álvarez et al. (2016), Vincent et al. (2013) and Maxted and Vincent (2021), suggest that Tunisia can be confirmed as a hotspot of CWR and WHP diversity in the Mediterranean. The results here presented show that $85 \%$ of the Tunisian flora is potentially useful either indirectly as a source of genetic diversity for crop improvement (CWR), or directly in ethnobotanical, medicinal or food uses. Indeed, the inventory developed includes $2468 \mathrm{CWR}$ and/or WHP taxa which is about $40 \%$ of the CWR reported for the North African region as a whole (Lala et al. 2018).

Mediterranean countries, including Tunisia, are considered central repositories of valuable genetic resources and are therefore responsible for their conservation (Labokas et al. 2018). Tunisia hosts several taxa adapted to extreme habitats, including salt and drought-resistant species, whose characteristics might be useful for genetic improvement of a wide range of cultivated relatives, especially in a scenario of climatic change. The prioritisation process led us to highlight $139 \mathrm{CWR}$, related to 60 crops or crop groups of socio-economic importance (Table 5), and 8 WHP high priority taxa that deserve to be included into urgent national conservation programs to meet the objectives of the global policies and legislative instruments to which Tunisia is committed.

This is, to date, the first CWR and WHP inventory for the North African region conducted at a national scale. It can offer the basis for further ecogeographic studies to evaluate in situ and ex situ status of the priority taxa and the development of more targeted synergistic conservation strategies. To this end, the integration of species-specific programs of in situ monitoring and conservation management into protected area management plans, with complementary ex situ conservation in the national genebank, is needed to decrease the risk of genetic erosion. Loss of genetic diversity is occurring in these areas without being acknowledged by monitoring teams because these socio-economically important species are not being targeted by protected area managers (Maxted et al. 2013). If these populations are not actively managed, the highest priority taxa will continue to suffer significant genetic erosion and are at risk of extinction. For ex situ conservation, the National Gene Bank of Tunisia (Banque Nationale de Gènes de Tunisie), which aims to conserve the Country's plant 
genetic resources, could undoubtedly play a leading role in conservation efforts, gene banking samples from distinct CWR and WHP populations, as well as in collaborating with in situ site managers in establishing a network of sites for in situ conservation, and vitally, in enabling access to material for use by plant breeders and farmers for crop improvement. Finally, the present work clearly showed the need of appropriate research on the quantification of CWR/WHP ecosystem services to assure the sustainable management of these PGR in the Tunisian arid and semi-arid environments and/or protected areas. Taking into account the contribution that these PGR give to national income or may have for the sustainability of major crop industries, further studies should be addressed to expand knowledge on the trade-off between their usage by the rural communities and related economic return in relation to the need for their conservation.

\section{Declarations}

Conflict of interest The authors declare no conflict of interest.

Open Access This article is licensed under a Creative Commons Attribution 4.0 International License, which permits use, sharing, adaptation, distribution and reproduction in any medium or format, as long as you give appropriate credit to the original author(s) and the source, provide a link to the Creative Commons licence, and indicate if changes were made. The images or other third party material in this article are included in the article's Creative Commons licence, unless indicated otherwise in a credit line to the material. If material is not included in the article's Creative Commons licence and your intended use is not permitted by statutory regulation or exceeds the permitted use, you will need to obtain permission directly from the copyright holder. To view a copy of this licence, visit http://creativecommons.org/licenses/by/4.0/.

\section{References}

Abd El Moneim AM, Elias SF (2003) Underground Vetch (Vicia sativa ssp. amphicarpa): a potential pasture and forage legume for dry areas in West Asia. J Agron Crop Sci 189:136-141. https://doi.org/10.1111/j.1745-7599.2006. 000 s2.x-i1

African Plant Database (2021) Version 3.4.0. Conservatoire et Jardin botaniques de la Ville de Genève and South African National Biodiversity Institute, Pretoria. http://www.villege.ch/musinfo/bd/cjb/africa/. Accessed January 2021

Allen E, Kell S, Magos Brehm J et al (2018) Priority CWR Species of the SADC region.https://doi.org/10.7910/DVN/ HSXUVE
Allen E, Gaisberger H, Magos Brehm J et al (2019) A crop wild relative inventory for Southern Africa: a first step in linking conservation and use of valuable wild populations for enhancing food security. Pl Genet Res 17:128-139. https:// doi.org/10.1017/S1479262118000515

Avagyan A (2008) Crop wild relatives in Armenia: diversity, legislation and conservation issues. In: Maxted N, FordLloyd BV, Kell SP, Iriondo JM, Dulloo E, Turok J (eds) Crop wild relative conservation and use. CAB International, Wallingford, pp 58-66

Ayed S, Bouhaouel I, Othmani A, Bassi FM (2021) Use of Wild Relatives in Durum Wheat (Triticum turgidum L. var $d u$ rum Desf.) Breeding Program: adaptation and stability in context of contrasting environments in Tunisia. Agronomy 11:1782. https://doi.org/10.3390/agronomy11091782

Ben Haj Jilani I, Zouaghi M, Ghrabi Z (2011) Ethnobotanical survey of medicinal plants in Northwest Tunisia. Curare 34(1-2):63-78

Ben Ismail H (2013) Edible wild vegetables used in North West of Tunisia. Indian J Res 2:9-11

Ben-Salah M, Barhoumi T, Abderraba M (2019) Ethnobotanical study of medicinal plant in Djerba island, Tunisia. Arab J Med Arom Plants 5(2):67-97. https://doi.org/10.48347/ IMIST.PRSM/ajmap-v5i2.16487

Bilz M, Kell SP, Maxted N, Lansdown RV (2011) European Red list of vascular plants. Luxembourg: Publications Office of the European Union. 130 pp. www.iucn.org/content/ european-red-list-vascular-plants-1

Borelli T, Hunter D, Powell B et al (2020) Born to eat wild: an integrated conservation approach to secure wild food plants for food security and nutrition. Plants 9:1299. https://doi.org/10.3390/plants9101299

Boukef K, Souissi HR, Balansard G (1982) Contribution à l'étude des plantes utilisées en médicine traditionnelle tunisienne. Pl Méd Phyto 16(4):260-279

Bretagnolle V, Gaba S (2015) Weeds for bees? A review. Agron Sustain Dev 35:891-909. https://doi.org/10.1007/s13593015-0302-5

Brummitt N, Bachman S (2010) Plants under pressure a global assessment. The first report of the IUCN sampled red list index for plants. Natural History Museum, London

Cardinale BJ, Duffy JE, Gonzalez A et al (2012) Biodiversity loss and its impact on humanity. Nature 486:59-67. https:// doi.org/10.1038/nature11148

Castañeda-Álvarez NP, Khoury CK, Achicanoy HA et al (2016) Global conservation priorities for crop wild relatives. Nature Pl 2:1-6. https://doi.org/10.1038/nplants.2016.22

CBD (Convention on biological diversity) (2012) Global strategy for plant conservation: 2011-2020. Botanic Gardens Conservation International, Richmond, U.K

CBD (Convention on Biological Diversity) (2015) Notification: Strengthening the in situ conservation of Plant Genetic Resources for Food and Agriculture through incorporation of Crop Wild Relatives under areas important for biodiversity in Protected Area Networks and other effective area-based conservation measures (Aichi Biodiversity Targets 7, 11, 12 and 13) (Global Strategy for Plant Conservation Targets 5, 6, 7 and 9). Ref.: SCBD/SAM/DC/ DCo/84808 (2015-092)

CBD (Convention on Biological Diversity) (2018) Decision adopted by the Conference of the Parties to the Convention 
on Biological Diversity. XIV meeting of the Conference of the Parties to the Convention on Biological Diversity, 30 November 2018, Sharm El-Sheikh, Egypt (CBD/COP/ DEC/14/34).https://www.cbd.int/doc/decisions/cop-14/ cop-14-dec-34-en.pdf

Ciancaleoni S, Raggi L, Barone G et al (2021) A new list and prioritization of wild plants of socioeconomic interest in Italy: toward a conservation strategy. Agroecol Sustain Food Syst. https://doi.org/10.1080/21683565.2021. 1917469

CoE (Council of Europe) (1979) Convention on the Conservation of European Wildlife and Natural Heritage. Bern, Switzerland. [Bern Convention]. http://conventions.coe. int/Treaty/EN/Treaties/Html/104.htm

Contreras-Toledo AR, Cortés-Cruz MA, Costich D et al (2018) A Crop Wild Relative Inventory for Mexico. Crop Sci 58:1292-1305. https://doi.org/10.2135/cropsci2017.07. 0452

Crespo-Herrera LA, Ortiz R (2015) Plant breeding for organic agriculture: something new? Agric Food Security 4:25. https://doi.org/10.1186/s40066-015-0045-1

Crop Trust (2019) The harlan and de wet crop wild relative inventory, https://www.cwrdiversity.org/checklist/ Accessed September 2021

Debbabi H, El Mokni R, Majdoub S et al (2020) The effect of pressure on the characteristics of supercritical carbon dioxide extracts from Calamintha nepeta subsp. nepeta. Biomed Chromatograp 34:e4871. https://doi.org/10.1002/ bmc. 4871

Dempewolf H, Baute G, Anderson J et al (2017) Past and future use of wild relatives in crop breeding. Crop Sci 57:1070-1082. https://doi.org/10.2135/cropsci2016.10. 0885

Dobignard A, Chatelain C (2010-2013) Synonymic and bibliographic index of North Africa plants. vol. 1-5

Domina G, El-Mokni R (2019) An inventory of the names of vascular plants endemic to $\mathrm{C}$ Mediterranean and described from Tunisia. Phytotaxa 409(3):105-128. https://doi.org/ 10.11646/phytotaxa.409.3.1

Dop MC, Kefi F, Karous O et al (2020) Identification and frequency of consumption of wild edible plants over a year in central Tunisia: a mixed-methods approach. Public Health Nutr 23(5):782-794. https://doi.org/10.1017/ S1368980019003409

Duru M, Therond O, Martin G et al (2015) How to implement biodiversity-based agriculture to enhance ecosystem services: a review. Agron Sustain Dev 35:1259-1281. https:// doi.org/10.1007/s13593-015-0306-1

El Mokni R (2004) Étude floristique et ethnobotanique du Parc National d'El Feîdja (Kroumirie): proposition d'une extension de l'aire protégée. Master de Recherche Scientifique. $276 \mathrm{p}$

Euro+Med (2006-) Euro+Med PlantBase - the information resource for Euro-Mediterranean plant diversity. Published on the Internet http://ww2.bgbm.org/EuroPlusMed/ Accessed 9/2021

Fabricant DS, Farnsworth NR (2001) The value of plants used in traditional medicine for drug discovery. Environ Health Persp 109:69-75. https://doi.org/10.1289/ehp.01109s169
FAO (2006) Food security. Policy Brief, June 2006, Issue 2. Available at: http://www.fao.org/forestry/131280e6f36f27e0091055bec28ebe830f46b3.pdf

FAO (2009a) Declaration of the world summit on food security. Rome. 7 pp. ftp://ftp.fao.org/docrep/fao/Meeting/018/ k6050e.pdf

FAO (2009b) International treaty on plant genetic resources for food and agriculture. international treaty on plant genetic resources for food and agriculture. Rome. Plant Production and Protection Division, FAO. Retrieved from http://www. fao.org/3/i0510e/I0510E.pdf

FAO (2011) Second global plan of action for the conservation and sustainable utilization of plant genetic resources for food and agriculture. Available at: http://www.fao.org/ docrep/015/i2624e/i2624e00.htm

FAO (2017) Voluntary Guidelines for the Conservation and Sustainable Use of Crop Wild Relatives and Wild Food Plants. Food and Agriculture Organization of the United Nations, Rome, 89 pp. http://www.fao.org/3/bs799e/ bs799e.pdf

FAO (2019a) The State of the World's Biodiversity for Food and Agriculture, Bélanger, J., and Pilling, D. (eds). FAO Commission on Genetic Resources for Food and Agriculture Assessments, Rome. http://www.fao.org/3/ CA3129EN/CA3129EN.pdf

FAO (2019b) FAOSTAT Statistical Database. License: CC BYNC-SA 3.0 IGO. Extracted from: http://www.fao.org/ faostat/en/\#data. Data of Access: 19-12-2019

FAO (2021) FAOSTAT Statistical Database. License: CC BYNC-SA 3.0 IGO. Extracted from: http://www.fao.org/ faostat/en/\#data/FBS. Data of Access: 23-04-2021

Fielder H, Hopkins J, Smith C et al (2012) UK wild species to underpin global food security: Species selection, genetic reserves and targeted collection. Crop Wild Relat 8:24-27

Fielder H, Brotherton P, Hosking J et al (2015) Enhancing the conservation of crop wild relatives in England. PLoS ONE 10:e0130804. https://doi.org/10.1371/journal.pone. 0130804

Ford-Lloyd BV, Maxted N, Kell SP (2008) Establishing conservation priorities for crop wild relatives. In: Maxted N, Ford-Lloyd BV, Kell SP et al (eds) Crop wild relative conservation and use. CAB Int, Wallingford, pp 110-119

Garzuglia M (2006) Threatened, endangered and vulnerable tree species: a comparison between FRA 2005 and the IUCN Red List. FAO, Forestry Department, Working Paper 108/E, Rome, Italy

Geraci A, Amato F, Di Noto G et al (2018) The wild taxa utilized as vegetables in Sicily (Italy): a traditional component of the Mediterranean diet. J Ethnobiol Ethnomed 14(1):14. https://doi.org/10.1186/s13002-018-0215-x

Godfray HCJ (2011) Food and biodiversity. Science 333:1231-1232. https://doi.org/10.1126/science.1211815

GRIIS (2018) Global register of introduced and invasive species. http://www.griis.org/

Hadjichambis ACH, Paraskeva-Hadjichambi D, Della A et al (2008) Wild and semi-domesticated food plant consumption in seven circum-Mediterranean areas. Internat $\mathrm{J}$ Food Sci Nutr 59:383-414. https://doi.org/10.1080/ 09637480701566495

Hajjar R, Hodgkin T (2007) The use of wild relatives in crop improvement: a survey of developments over the last 20 
years. Euphytica 156:1-13. https://doi.org/10.1007/ s10681-007-9363-0

Hannachi H, Sommerlatte H, Breton C et al (2009) Oleaster (var. sylvestris) and subsp. cuspidata are suitable genetic resources for improvement of the olive (Olea europaea subsp. europaea var. europaea). Genet Resour Crop Evol 56:393-403

Harlan JR, de Wet JMJ (1971) Towards a rational classification of cultivated plants. Taxon 20:509-517. https://doi.org/10. 2307/1218252

Hasnaoui O, Bouazza M, Benali O, Thinon M (2011) Ethnobotanic study of Chamaerops humilis L. var. argentea Andre (Arecaceae) in Western Algeria. Agric J 6:1-6

Heywood VH (1999) Use and potential of wild plants in farm households. Farm systems management series 15. FAO, Rome

Heywood VH (2011) Crop wild relatives in the project countries. In: Hunter D, Heywood V (eds) Crop wild relatives: a manual of in situ conservation. Bioversity International, pp 31-45

IOC (International Olive Council) (2021) Available online: http://www.internationaloliveoil.org

IPNI (2020) International Plant Names Index. Published on the Internet http://www.ipni.org, The Royal Botanic Gardens, Kew, Harvard University Herbaria and Libraries and Australian National Botanic Gardens. Retrieved September 2021

IUCN (2012) IUCN Red List Categories and Criteria: Version 3.1. Second edition. IUCN, Gland, Switzerland and Cambridge, UK

IUCN (2021) The IUCN Red List of Threatened Species. Version 2021-2. http://www.iucnredlist.org. Downloaded $15 / 10 / 2021$

Jacobsen SE, Sørensen M, Pedersen SM, Weiner J (2015) Using our agrobiodiversity: plant-based solutions to feed the world. Agron Sustain Dev 35:1217-1235. https://doi.org/ 10.1007/s13593-015-0325-y

Jarvis S, Fielder H, Hopkins J et al (2015) Distribution of crop wild relatives of conservation priority in the UK landscape. Biol Conserv 191:444-451. https://doi.org/10.1016/j. biocon.2015.07.039

Karous O, Ben Haj Jilani I, Ghrabi-Gammar Z (2021) Ethnobotanical study on plant used by semi-nomad descendants' community in Ouled Dabbeb-Southern Tunisia. Plants 10(4):642. https://doi.org/10.3390/plants10040642

Kell SP, Knüpffer H, Jury SL et al (2005) Catalogue of crop wild relatives for Europe and the mediterranean. University of Birmingham, Birmingham

Kell SP, Knüpffer H, Jury SL et al (2008) Crops and wild relatives of the Euro-Mediterranean region: making and using a conservation catalogue. In: Maxted N, Ford-Lloyd BV, Kell SP et al (eds) Crop wild relative conservation and use. CAB International, Wallingford, pp 69-109

Kell SP, Maxted N, Bilz M (2012) European crop wild relative threat assessment: knowledge gained and lessons learnt. In: Maxted N, Dulloo ME, Ford-Lloyd BV et al (eds) Agrobiodiversity conservation: securing the diversity of crop wild relatives and landraces. CAB International, Wallingford, UK, pp 218-242

Kell SP, Qin H, Chen B et al (2015) China's crop wild relatives: Diversity for agriculture and food security. Agric Ecosyst
Environ 209:138-154. https://doi.org/10.1016/j.agee. 2015.02.012

Kell SP, Ford-Lloyd BV, Magos Brehm J et al (2017) Broadening the base, narrowing the task: prioritizing crop wild relative taxa for conservation action. Crop Sci 57:1042-1058. https://doi.org/10.2135/cropsci2016.10. 0873

Keller G, Mndiga H, Maass B (2005) Diversity and genetic erosion of traditional vegetables in Tanzania from the farmer's point of view. Pl Genet Res 3(3):400-413. https:// doi.org/10.1079/PGR200594

Khaldi PR, Saaidia PB (2017) Analyse de la filière céréaliere en Tunisie et identification des principaux points de dysfonctionnement à l'origine des pertes (No. GCP/RNE/004/ ITA). FAO. http://www.onagri.nat.tn/uploads/Etudes/ RapportIVF.pdf

Labokas J, Maxted N, Kell SP et al (2018) Development of national crop wild relative conservation strategies in European countries. Genet Res Crop Evol 65(5):1385-1403. https://doi.org/10.1007/s10722-0180621-x

Lala S, Amri A, Maxted N (2018) Towards the conservation of crop wild relative diversity in North Africa: checklist prioritization and inventory. Genet Res Crop Evol 65:113-124. https://doi.org/10.1007/s10722-017-0513-5

Lamrani-Alaoui M, Hassikou R (2018) Rapid risk assessment to harvesting of wild medicinal and aromatic plant species in Morocco for conservation and sustainable management purposes. Biodiv Conserv 27:2729-2745. https://doi.org/ 10.1007/s10531-018-1565-3

Landucci F, Panella L, Lucarini D et al (2014) A prioritized inventory of crop wild relatives and wild harvested plants of Italy. Crop Sci 54:1628-1644. https://doi.org/10.2135/ cropsci2013.05.0355.

Lasram A, Masmoudi MM, Mechlia NB (2017) Effect of high temperature stress on wheat and barley production in Northern Tunisia. In: Ouessar M, Gabriels D, Tsunekawa A, Evett $S$ (eds) Water and land security in drylands: response to climate change. Springer, Cham, pp 27-34

Lavania UC (2005) Genomic and ploidy manipulation for enhanced production of phyto-pharmaceuticals. Pl Genet Res 3:170-177. https://doi.org/10.1079/PGR200576

Le Floc'h É (1983) Contribution à une étude ethnobotanique de la flore tunisienne. Imprimerie Officielle de la Tunisie. Tunis; $402 \mathrm{p}$

Le Floc'h É, Boulos L, Vela E (2010) Catalogue synonymique commenté de la flore de Tunisie. Simpact

Le Houérou HN (2002) Cacti (Opuntia spp.) as a fodder crop for marginal lands in the Mediterranean basin. In IV International Congress on Cactus Pear and Cochineal. Acta Hort $581: 21-46$

Lentini F, Venza F (2007) Wild food plants of popular use in Sicily. J Ethnobiol Ethnomed 3:15. https://doi.org/10. 1186/1746-4269-3-15

Libiad M, Khabbach A, El Haissoufi M et al (2020) Ex-situ conservation of single-country endemic plants of Tunisia and northern Morocco (Mediterranean coast and Rif region) in seed banks and botanic gardens worldwide. Kew Bull 75:46. https://doi.org/10.1007/s12225-020-09903-6

Lybbert TJ, Aboudrare A, Chaloud D et al (2011) Booming markets for Moroccan Argan oil appear to benefit some 
rural households while threatening the endemic argan forest. Proc Natl Acad Sci 108(34):13963-13968. https:// doi.org/10.1073/pnas.1106382108

Magos Brehm J, Maxted N, Ford-Lloyd BV, Martins- Loução MA (2008) National inventories of crop wild relatives and wild harvested plants: case-study for Portugal. Gen Res Crop Evol 55:779-796. https://doi.org/10.1007/s10722007-9283-9

Magos Brehm J, Maxted N, Martins-Loução MA, Ford-Lloyd BV (2010) New approaches for establishing conservation priorities for socio-economically important plant species. Biodiv Conserv 19(9):2715-2740. https://doi.org/10.1007/ s10531-010-9871-4

Magos Brehm J, Kell SP, Thormann I et al (2017) Interactive Toolkit for Crop Wild Relative Conservation Planning version 1.0. University of Birmingham, Birmingham, UK and Bioversity International, Rome, Italy. Available at http://www.cropwildrelatives.org/conservation-toolkit/

Mammadov J, Buyyarapu R, Guttikonda SK et al (2018) Wild Relatives of Maize, Rice, Cotton, and Soybean: treasure troves for tolerance to biotic and abiotic stresses. Frontiers Pl Sci 9:1-21. https://doi.org/10.3389/fpls.2018.00886

Maxted N, Hawkes JG, Guarino L, Sawkins M (1997) Towards the selection of taxa for plant genetic conservation. Genet Resour Crop Evol 44:337-348. https://doi.org/10.1023/A: 1008643206054

Maxted N, Ford-Lloyd BV, Jury S et al (2006) Towards a definition of a crop wild relative. Biodiv Conserv 15:2673-2685. https://doi.org/10.1007/s10531-005-54096

Maxted N, Scholten M, Codd R, Ford-Lloyd B (2007) Creation and use of a national inventory of crop wild relatives. Biol Conserv 140:142-159. https://doi.org/10.1016/j.biocon. 2007.08.006

Maxted N, Kell SP (2009) Establishment of a global network for the in situ conservation of crop wild relatives: Status and needs. FAO Commission on Genetic Resources for Food and Agriculture. www.fao.org/docrep/013/i1500e/ i1500e18d.pdf

Maxted N, Kell SP, Toledo Á et al (2010) A global approach to crop wild relative conservation: securing the gene pool for food and agriculture. Kew Bull 65:561-576. https://doi. org/10.1007/s12225-011-9253-4

Maxted N, Magos Brehm J, Kell SP (2013) Resource book for preparation of national conservation plans for crop wild relatives and landraces. University of Birmingham, United Kingdom. http://www.fao.org/fileadmin/templates/ agphome/documents/PGR/PubPGR/ResourceBook/ TEXT_ALL_2511.pdf

Maxted N, Hunter D, Ortiz Rios RO (2020) Plant genetic conservation. Cambridge University Press, Cambridge, p 560

Maxted N, Vincent H (2021) Review of congruence between global crop wild relative hotspots and centres of crop origin/diversity. Genet Res Crop Evol 68:1283-1297. https://doi.org/10.1007/s10722-021-01114-7

Médail F, Quézel P (1999) Biodiversity hotspots in the mediterranean basin: setting global conservation priorities. Conserv Biol 13:1510-1513. https://doi.org/10.1046/j. 1523-1739.1999.98467.x

MEDD : Ministère de'l'Environnement et du Développement Durable, Tunisia, 2009. Pour une stratégie sur la diversité biologique à'l'horizon 2020. Volume II: La Biodiversité Vegetale, pp 113

Menendez-Baceta G, Aceituno-Mata L, Tardío J et al (2012) Wild edible plants traditionally gathered in Gorbeialdea (Biscay, Basque Country). Genet Resour Crop Evol 59:1329-1347. https://doi.org/10.1007/s10722-011-9760$\mathrm{z}$

Mezghani N, Ben Amor J, Spooner DM et al (2017) Multivariate analysis of morphological diversity among closely related Daucus species and subspecies in Tunisia. Genet Resour Crop Evol 64:2145-2159. https://doi.org/10.1007/s10722017-0505-5

Mezghani N, Khoury CK, Carver D et al (2019) Distributions and conservation status of carrot wild relatives in Tunisia: a case study in the Western Mediterranean Basin. Crop Sci 59:2317-2328. https://doi.org/10.2135/cropsci2019.05. 0333

Ministère des Affaires Locales et de l'Environnement (2019) Sixième Rapport National sur la Biodiversité en Tunisie. United Nations Development Program-UNDP, Tunis

Mithen RF, Lewis BG (1988) Resistance to Leptosphaeria maculans in hybrids of Brassica oleracea and Brassica insularis. J Phytopathol 123(3):253-258

Molina M, Pardo-de-Santayana M, Tardío J (2016) Natural Production and cultivation of mediterranean wild edibles. In: de Sánchez-Mata MC, Tardío J (eds) Mediterranean wild edible plants: ethnobotany and food composition tables. Springer, New York, pp 81-107

Morales J, Pérez-Jordà G, Peña-Chocarro L et al (2013) The origins of agriculture in North-West Africa: macro-botanical remains from Epipalaeolithic and Early Neolithic levels of Ifri Oudadane (Morocco). J Archaeol Sci 40(6):2659-2669. https://doi.org/10.1016/j.jas.2013.01. 026

Mponya NK, Magombo ZLK, Pungulani L et al (2020) Development of a prioritised checklist of crop wild relatives for conservation in Malawi. African Crop Sci J 28:279-311. https://doi.org/10.4314/acsj.v28i2.12

Myers N, Mittermeier RA, Mittermeier CG et al (2000) Biodiversity hotspots for conservation priorities. Nature 403:853-858. https://doi.org/10.1038/35002501

Nassif F, Tanji A (2013) Gathered food plants in Morocco: The long- forgotten species in ethnobotanical research. Life Sci Leaf 3:17-54

Neffati M (2016) Les PPAMs en Tunisie: Un secteur prometteur pour la diversification de la production agricole et pour assurer le développement durable. Presented at the Séminaire CEDDEM, Aix-en-Provence, France, p. 8. http:// www.ceddem.org/maj/upload/publications/fichier_46.pdf

ONAGRI (Observatoire National de l'Agriculture) (2018) Annual Technical Report for Durum Wheat Cultivation. http://www.onagri.tn/uploads/veille/nouveau-livre/bled. pdf

Padulosi S, Heywood V, Hunter D, Jarvis A (2011) Underutilized species and climate change: current status and outlook. In: Crop adaptation to climate change. John Wiley and Sons, Ltd, pp. 507-521. https://doi.org/10.1002/ 9780470960929.ch35

Petropoulos SA, Karkanis A, Martins N, Ferreira IC (2018) Edible halophytes of the Mediterranean basin: potential 
candidates for novel food products. Trends Food Sci Technol 74:69-84

PGRDEU (National Inventory of Plant Genetic Resources) (2021) Federal Ministry of Food, Agriculture and Consumer Protection: Bonn, Germany. https://pgrdeu.genres. $\mathrm{de} /$

Phillips J, Asdal $\AA$, Magos Brehm J et al (2016) In situ and ex situ diversity analysis of priority crop wild relatives in Norway. Div Distr 22:1112-1126. https://doi.org/10.1111/ ddi. 12470

Pinela J, Carvalho AM, Ferreira ICFR (2017) Wild edible plants: Nutritional and toxicological characteristics, retrieval strategies and importance for today's society. Food Chem Toxicol 110:165-188. https://doi.org/10.1016/ j.fct.2017.10.020

POWO (2019) Plants of the World Online. Facilitated by the Royal Botanic Gardens, Kew. Published on the Internet; http://www.plantsoftheworldonline.org/ Retrieved September 2021

Raab-Straube von E, Henning T, Berendsohn W et al (2016) Sisyphos close to the mountain top: Euro+Med PlantBase is nearing its completion. Presented at the XV OPTIMA Meeting, Montpellier, France, p 176. https://doi.org/10. 13140/RG.2.1.4121.8803

Rahman W, Magos Brehm J, Maxted N (2019) Setting conservation priorities for the wild relatives of food crops in Indonesia. Gen Res Crop Evol 66:809-824. https://doi.org/ 10.1007/s10722-019-00761-1

Rallo L, Barranco D, Díez CM et al (2018) Strategies for Olive (Olea europaea L.) breeding: cultivated genetic resources and crossbreeding. In: Al-Khayri JM, Jain SM, Johnson DV (eds) Advances in plant breeding strategies: fruits, vol 3. Springer, Cham, pp 535-600

Reeves TG, Thomas G, Ramsay G (2016) Save and grow in practice: maize, rice, wheat-a guide to sustainable cereal production. UN Food and Agriculture Organization, Rome. http://www.fao.org/3/a-i4009e.pdf

Rowe J, Maxted N (2019) Vicia sativa subsp. amphicarpa. The IUCN Red List of Threatened Species 2019: e.T135133262A135133494. https://doi.org/10.2305/ IUCN.UK.2019-2.RLTS.T135133262A135133494.en. Downloaded on 26 September 2021

Rubiales D, Fondevilla S, Chen W et al (2015) Achievements and challenges in legume breeding for pest and disease resistance. Critical Rev Pl Sci 34:195-236. https://doi.org/ 10.1080/07352689.2014.898445

Sadok W, Schoppach R, Ghanem ME et al (2019) Wheat drought-tolerance to enhance food security in Tunisia, birthplace of the Arab Spring. Eur J Agron 107:1-9. https:// doi.org/10.1016/j.eja.2019.03.009

Sánchez-Mata MC, Cabrera Loera RD, Morales P et al (2012) Wild vegetables of the Mediterranean area as valuable sources of bioactive compounds. Gen Res Crop Evol 59(3):431-443. https://doi.org/10.1007/s10722-011-96936

Schultes RE (1991) The reason for ethnobotanical conservation. In: Akerele O, Heywood V, Synge H (eds) Conservation of medicinal plants. Cambridge University Press, New York, pp 65-75
Sillero JC, Moreno MT, Rubiales D (2005) Sources of resistance to crenate broomrape among species of Vicia. Pl Disease 89(1):23-27

Simon PW, Rolling WR, Senalik D et al (2020) Wild carrot diversity for new sources of abiotic stress tolerance to strengthen vegetable breeding in Bangladesh and Pakistan. Crop Sci 61:163-176. https://doi.org/10.1002/csc2.20333

Sobeh M, Rezq S, Cheurfa M et al (2020) Thymus algeriensis and Thymus fontanesii: chemical composition, in vivo antiinflammatory, pain killing and antipyretic activities: a comprehensive comparison. Biomolecules 10(4):599. https://doi.org/10.3390/biom10040599

Sofi F, Abbate R, Franco G, Casini A (2010) Accruing evidence on benefits of adherence to the Mediterranean diet on health: an updated systematic review and meta-analysis. Clin Nutr 92(5):1189-1196

Sofowora A (1993) Medicinal plants and traditional medicine in Africa. Spectrum Books Ltd., Ibadan

Soumaya K, Chaouachi F, Ksouri R, El Gazzah M (2013) Polyphenolic composition in different organs of Tunisia populations of Cynara cardunculus L. and their antioxidant activity. J Food Nutrition Res 1:1-6

Termote C, Van Damme P, Dhed'a Djailo B (2011) Eating from the wild: Turumbu, Mbole and Bali traditional knowledge on non-cultivated edible plants, District Tshopo, DRCongo. Genet Resour Crop Evol 58:585-618. https:// doi.org/10.1007/s10722-010-9602-4

The Plant List (2021) Version 1.1. Published on the Internet; http://www.theplantlist.org/ Accessed September 2021.

Thormann I, Kell SP, Magos Brehm J et al (2017) CWR checklist and inventory data template v"1 ". https://doi.org/ 10.7910/DVN/B8YOQL

Ulian T, Diazgranados M, Pironon S et al (2020) Unlocking plant resources to support food security and promote sustainable agriculture. Pl People Planet 2:421-445. https:// doi.org/10.1002/ppp3.10145

UNEP (United National Environment Programme) (1992) Convention on Biological Diversity: Text and Annexes. United Nations Environment Programme, Nairobi

USDA, Agricultural Research Service, National Plant Germplasm System (2021) Germplasm Resources Information Network (GRIN Taxonomy). National Germplasm Resources Laboratory, Beltsville, Maryland. URL: https:// npgsweb.ars-grin.gov/gringlobal/taxon/ taxonomysearchcwr. Accessed September 2021

Vavilov NI (1926) The centres of origin of cultivated plants. Works Appl Bot Pl Breeding 16(2):1-248

Vincent H, Wiersema J, Kell SP et al (2013) A prioritized crop wild relative inventory to help underpin global food security. Biol Conserv 167:265-275. https://doi.org/10.1016/j. biocon.2013.08.011

Vollbrecht E, Sigmon B (2005) Amazing grass: developmental genetics of maize domestication. Biochem Soc $T$ 33:1502-1506. https://doi.org/10.1042/BST20051502

WFP (World Food Programme) (2011) Secondary data analysis of the food security situation in Tunisia. Regional Bureau for the Middle East, ODC. https://documents.wfp.org/ stellent/groups/public/documents/ena/wfp236106.pdf

Willett WC (2006) The Mediterranean diet: science and practice. Public Health Nutr 9:105-110. https://doi.org/10. 1079/PHN2005931 
Zouari N, Ayadi I, Fakhfakh N et al (2012) Variation of chemical composition of essential oils in wild populations of Thymus algeriensis Boiss et Reut., a North African endemic Species. Lipids Health Dis 11:28. https://doi.org/ 10.1186/1476-511X-11-28

Zouari S, Ketata M, Boudhrioua N, Ammar E (2013) Allium roseum L. volatile compounds profile and antioxidant activity for chemotype discrimination: case study of the wild plant of Sfax (Tunisia). Ind Crops Prod 41:172-178. https://doi.org/10.1016/j.indcrop.2012.04.020

Zouari S, Ayadi I, Fakhfakh N et al (2014) Essential oil variation in wild populations of Artemisia saharae (Asteraceae) from Tunisia: chemical composition, antibacterial and antioxidant properties. Bot Stud 55:76. https://doi.org/10. 1186/s40529-014-0076-0

Zrira S (2013) The value chain of aromatic and medicinal plants in the Maghreb. Acta Hortic 997:297-304. https://doi.org/ 10.17660/ActaHortic.2013.997.36

Publisher's Note Springer Nature remains neutral with regard to jurisdictional claims in published maps and institutional affiliations. 